Qualitative Research on Work-Family in the Management Field: A Review (Accepted for Publication in Applied Psychology: An International Review)

\author{
Mina Beigi* \\ Liverpool John Moores University \\ Email: M.Beigi@ljmu.ac.uk \\ * Corresponding author \\ Melika Shirmohammadi \\ Texas A\&M University \\ Email: melika@tamu.edu
}




\title{
Qualitative Research on Work-Family in the Management Field: A Review
}

\begin{abstract}
Despite a proliferation of work-family literature over the past three decades, studies employing quantitative methodologies significantly outweigh those adopting qualitative approaches. In this paper, we intend to explore the state of qualitative work-family research in the management field and provide a comprehensive profile of the 152 studies included in this review. We synthesize the findings of qualitative work-family studies and provide six themes including parenthood, gender differences, cultural differences, family-friendly policies and non-traditional work arrangements, coping strategies, and under-studied populations. We also describe how findings of qualitative work-family studies compare to that of quantitative studies. The review highlights seven conclusions in the current qualitative literature: a limited number of qualitative endeavours, findings worth further attention, convergent foci, the loose use of work-family terminology, the neglect of a variety of qualitative research approaches, quantitative attitudes towards qualitative research, and insufficient reporting of research methods. In addition, implications for future researchers are discussed.
\end{abstract}

Keywords: Work-family interface, work-family, family-friendly policy, qualitative, review 


\section{Introduction}

Quantitative research methodologies have dominated management research for decades. The popularity of quantitative endeavours is evidenced by the significantly disproportionate number of quantitative studies published in top management journals compared to the number of qualitative studies (Gephart, 2004). This is also the case for workfamily research conducted by management scholars (Greenhaus \& Parasuraman, 1999). Despite a proliferation of work-family literature over the past three decades (Eby, Casper, Lockwood, Bordeaux, \& Brinley, 2005), studies employing quantitative methodologies substantially outweigh those adopting qualitative approaches (Casper, Eby, Bordeaux, Lockwood, \& Lambert, 2007).

The lack of methodological diversity in work-family research deprives researchers of the potential contributions of qualitative research. Qualitative research, which emphasizes socially constructed reality, involves a close relationship between the researcher and the phenomenon under study and captures the processes and meaning of a phenomenon in its natural setting. Unlike quantitative studies that stress measurement and causal relationships, this type of inquiry seeks to understand how individuals attribute meaning to social experiences (Denzin \& Lincoln, 2000). This approach towards research is flexible and emergent; therefore, it is well suited for expressing unanticipated phenomena and providing a holistic description of realities that cannot be predetermined in terms of variables (Gephart, 2004).

Radcliffe and Cassell (2014) conducted a qualitative study with the goal of developing a framework with which to shed light on work-family conflict (WFC) resolution in dual-earner couples. They sought to understand how couples negotiate their professional and personal responsibilities when encountering a conflict between work and family spheres. To answer these questions, the researchers interviewed 48 individuals ( 24 dual-earner 
couples) who had multiple occupations and dependent children. Data analysis revealed two types of work-family decision-making among the couples: anchoring and daily decisions. Each type of decision was impacted by multiple factors, including beliefs, values, and preferences. Their findings showed that couples' decisions in regard to WFC do not follow a "logical sequence" and involve a complex negotiating process. The authors present a framework that encompasses their findings and explores how these findings interrelate. It would not have been possible to gain such insight had they employed quantitative techniques.

In this paper, we aim to explore the state of qualitative work-family research in the management field; conducting a review study can serve this objective. As Lee, Mitchell, and Sablynski (1999), who reviewed the qualitative research methods used in behavioural and vocational psychology, have suggested, it is healthy for all academic fields to "pause periodically and take stock of what they have been doing and where they are going" (Lee et al., 1999, p. 161).

This review seeks to provide a big picture of qualitative scholarly endeavours on work-family and aims to answer the four following questions. The first two questions help generate a comprehensive profile of the qualitative endeavours in the work-family field. The third and fourth questions will focus on the findings and theoretical contributions of the reviewed studies.

1. What is the state of qualitative work-family studies in the management field?

2. What qualitative methodologies and methods are adopted by work-family researchers in the management field?

3. What do we know based on qualitative work-family studies in the management field?

4. How do findings of qualitative work-family studies in the management field compare with that of quantitative studies and what are their theoretical contributions? 
The scarcity of qualitative studies on work-family allows us to extend the limits of the review to all journals listed in Social Sciences Citation Index (SSCI) in the management field, and other close fields that publish management-related studies, without having any time boundaries. Additionally, the limited number of qualitative publications on work-family enables us to include many different conceptualizations of the interface between work and family and the family-friendly initiatives that are described in the methods section.

In the remainder of this paper, we briefly outline the work-family interface (WFI) and provide a snapshot of review studies on the topic. Subsequently, we describe our methods and screening process. Finally, we present the results, followed by discussion and implications.

\section{Literature Review}

\section{Work-Family Interface}

Several terms have been coined to express how work and family impact or combine with one another. Among the terminologies that describe a combination of personal and professional arenas of life, WFC (Geenhaus \& Beutell, 1985) and work-family/life balance have received the greatest scholarly and journalistic attention, respectively. The former, supported by role theory (Kahn, Wolfe, Quinn, Snoek, \& Rosenthal, 1964), argues that mutually incompatible pressures from work/family roles cause inter-role conflict and make the fulfilment of either family or work expectations difficult (Greenhaus \& Beutell, 1985). The latter adopts a balance perspective and refers to "the extent to which individuals are equally engaged in and equally satisfied with work and family roles" (Greenhaus, Collins, \& Shaw, 2003, p. 513).

Work-family spillover (Crouter, 1984; Zedeck, 1992), work-family facilitation (Frone, Yardley, \& Markel, 1997) or enrichment (Greenhaus \& Powell, 2006), work-family border (Clark, 2000), work-family boundary (Ashforth et al., 2000), and work-family integration (Kanter, 1977) are among other concepts introduced to show the linkage between 
work and family spheres. Irrespective of the specific terminology, the aforementioned concepts have added new perspectives to work-family literature, thus moving the field forward.

\section{Review Studies on Work-Family}

Eby et al. (2005) classified review studies on work-family into two categories: narrative and quantitative. Narrative reviews selectively combine previous studies and provide new frameworks or models (e.g., Greenhaus \& Beutell, 1985; Kelly et al., 2008) or discuss propositions for future research (e.g., Greenhaus \& Powell, 2006). Review studies in this category have made significant contributions to the literature by providing fresh perspectives; however, the such studies do not present an exact account of the previous publications.

The second group of reviews (e.g., Allen et al., 2012), namely meta-analysis, combine the results of previous studies using quantitative methods. Several meta-analyses have focused on examining the relationship between the WFI and its antecedents, e.g., social support (Kossek, Pichler, Bodner, \& Hammer, 2011) and family-friendly work environments (Mesmer-Mangus \& Viswesvaran, 2006). In addition, some meta-analytic studies have considered the WFI outcomes, including life-job satisfaction (Kossek \& Ozeki, 1998) and psychological distress (Major, Klein, \& Ehrhart, 2002).

To date, a few reviews have partially synthesized the research findings of qualitative work-family studies. One narrative review included both quantitative and qualitative studies on the WFI and family-friendly policies. Kossek and Ozeki (1999) combined the findings of 27 quantitative articles examining the relationship between WFC and major organizational work outcomes such as turnover and commitment. They also integrated the findings of 19 qualitative studies to show the effects of human resource policies that were aimed at reducing conflict on the same work outcomes (Kossek \& Ozeki, 1999). 
Of the studies reviewing the work-family literature, one review content-analysed both 170 quantitative and 20 exploratory qualitative work-family studies published in 14 IO/OB journals (Eby et al., 2005). The authors identified several trends recurring in the literature in nine topical areas. According to the authors, the majority of studies focused on predicting relationships between work and family variables (i.e., quantitative studies) instead of exploratory research questions (i.e., qualitative studies).

In a narrative review, Gatrell, Burnett, Cooper, and Sparrow (2013) combined the results of quantitative and qualitative studies, monographs, and edited book chapters in a review of the work-life and parenthood literature. Following Eby et al.'s (2005) approach, the authors searched business, health, and social sciences databases and found 162 articles, in addition to 32 research monographs/edited collections. The authors elaborated on the narrow definition of work-life balance (WLB) used within the fields of organizational psychology, sociologies of work and family, and management. They argued that the current definition primarily explains WLB in the context of heterosexual dual-career parents. The review offered a framework with which future researchers might address the issue of definition and inequality by expanding the scope to include themes such as class, gender difference, and enrichment.

Previous reviews have suggested that the field of work-family should make greater use of qualitative research design (Casper et al., 2007) to better answer exploratory questions, reflect experiences of under-studied groups, and introduce multiple sources of data. However, Casper et al.'s (2007) review of research methodologies used in work-family research in the IO/OB literature included only three studies with an overall qualitative research design. To our knowledge, no previous papers have reviewed and synthesized the work-family scholarship with a particular focus on qualitative studies.

\section{Methods}




\section{Literature Search and Inclusion Criteria}

In this study, we used the ISI Web of Knowledge as our primary database. This database encompasses all journals indexed in SSCI, thus providing a respectable profile of management journals while limiting the number of publications. Furthermore, this database includes all leading journals that are venues for publishing original and/or innovative papers in the management field (e.g., Academy of Management Journal).

We searched the terms "work-family”, "work/family”, "work-life”, “work/life", “work-nonwork", “work/nonwork”, “work, family”, "family, work”, “work and family”, “work-home", "work/home”, "work-non-work", “work and personal and lives”, "work and personal and life", "work and family and lives", "work and family and life", "professional and family and lives" and "professional and family and life" to find articles on the WFI. We also searched the terms "family responsive polic*", "family and human resource polic*", "alternative work schedule*”, “flextime”, "family friendly", "childcare”, “dependent care”, “elder care", "parent and work", “dual-earner", "dual-career", and "maternity leave” to find additional articles related to the WFI or family-friendly policies. We then narrowed the search results to qualitative studies utilizing the keywords "qualitative", "narrative", "case study", "ethnography", "phenomenolog*”, "grounded theory”, "focus group”, "field study”, “content analy*”, "interview*”, “observation", “discourse analysis", "naturalistic", "constant compar*”, “conversation analysis”, “descriptive study”, “exploratory”, “field study”, "hermeneutic", "semiotic", "purpos* sampl*" or "theoretical sampl*". In addition, we limited our search by language to English, document type to article, and Index to "Social Sciences Citation Index (SSCI) - 1900-present". We included seven Web of Science categories: Industrial Relations-Labour, Management, Business, Applied Psychology, Sociology, Social Sciences Interdisciplinary, and Public Administration. Our initial search returned 1113 search results. 
Next, we read and screened papers based on two screening questions. We first examined whether the paper had a major or minor focus on the WFI among individuals or work-family policies in organizational contexts. We operationalized this criterion by reading the title, abstract, keywords, research purpose or research questions of each article while looking for words/concepts pertaining to the WFI. We also included studies that focused on family-friendly policies in organizational contexts. Although we are aware that articles focusing on national-level work-family policies are central to the work-family literature, we speculated that focusing on organizational contexts would allow for a deep understanding of work-family in the management field.

Our second inclusion criterion was whether the paper used a qualitative approach as the main research methodology. We excluded papers that adopted mixed-method approaches to study work-family for two main reasons. First, a great number of the mixed-method studies did not adopt a pure qualitative approach and widely depended on quantitative surveys and then added follow-up qualitative interviews or surveys. Second, the purpose of this study was to highlight the profile of the qualitative studies neglected by the field; therefore, including the mixed-method studies would not serve our purpose. In total, 152 articles were selected for inclusion. Table 1 lists the frequency of articles by journal.

Insert Table 1 about here

\section{Content Analysis and Coding Process}

Other than coding the 152 papers for general information, including publication year, author/s, and journal, we coded papers for the following: country/ies wherein the research was conducted, guiding theory, work-family terminology, research methodology, research methods, and findings. We briefly describe our coding schema below.

We kept a record of the papers' research purposes and focus areas as stated in each publication. To code guiding theories of the papers, we recorded any theory the researchers 
had adopted to describe the phenomenon of work-family or to shape their research purpose or questions. We coded research paradigm for different qualitative methodologies including naturalistic inquiry/generic, case study, phenomenology, grounded theory, narrative, and ethnography.

The largest part of our coding sheet recorded research methods. This section comprised each study's participants' characteristics, data collection method including interview, focus group, open-ended survey, observation, shadowing, and documents. We also determined whether the authors provided any information as to their subjectivity statement. Moreover, we recorded data analysis techniques (e.g., constant comparative method, phenomenological analysis, content analysis, and narrative analysis), identified whether a data analysis software was used, and determined whether the steps used in the analysis were reported. In addition, we documented whether the authors had provided example/s of how their raw data had been translated into results. Finally, we summarized the major findings of each article.

Insert Table 2 about here

\section{Findings}

\section{Question 1. What is the State of Qualitative Work-Family Studies in the Management}

\section{Field?}

Overview. The 152 articles identified for review were published in 70 different journals. The journals that had the most frequent publications were Gender Work and Organization (17 articles), Human Relations (9 articles), Personnel Review (5 articles), the International Journal of Human Resource Management (5 articles), the Academy of Management Journal (5 articles), Gender \& Society (4 articles), the Journal of Vocational Behavior (4 articles), the Journal of Management \& Organization (4), New Technology Work and Employment (4 articles), Journal of Managerial Psychology (4), and Work Employment 
and Society (4). The third column of Table 2 provides the full list of journals and Table 1 lists journals based on the frequency of the papers published in them.

Among the shortlisted articles, the earliest qualitative paper on work-family was published in 1992. The number of qualitative studies published each year has increased steadily over the past three decades. To provide a clear picture, we present the number of publications over a series of five-year periods. There were four publications between 1990 and 1995. Thereafter, the number increased to eight during the period 1996-2000, followed by fifteen publications from 2001 to 2005 . There was a significant increase in the number of qualitative studies published in the next five-year period from 2006 to 2010 (47 articles) and another major increase from 2011 to 2015 (78 articles).

Country. There were 33 (21.7\%) studies involving participants from North America (39 US, Eight Canada), 52 (34.2\%) involving European samples (including 30 with UK participants), 20 (13.1\%) involving participants in Australia (sixteen Australia, four New Zealand), nine (5.9\%) involving Asian participants, one involving (.6\%) Latin America, one $(.6 \%)$ involving African participants and one (.06\%) involving Russian participants. Ten (6.5\%) studies did not mention the geographical context of the study, and eleven $(7.2 \%)$ involved participants from more than one country: seven (4.6\%) involved participants from two or more European countries (including the UK), and four (2.6\%) involved a mixture of participants from the US and Europe (three studies), and the US and Canada. One study involved participants from India and other countries that were not mentioned.

Work-family terminology. Fifty-seven (37.50\%) studies utilized the term "worklife/family balance" to refer to the interface between work and family. Fourteen (9.2\%) studies employed "work-family conflict/s". Twenty-nine (19.07\%) studies used other terms that refer to the WFI, including "work-family/life" (home or non-work) combined with “interface” (seven studies), "integration" (four studies), “interaction" (three studies), 
"boundary" (five studies), and "intersection" (three studies). Other terminologies referring to the WFI included: "work-family/life linkage” (one study), "management” (two studies), “issue” (one study), “adaptation” (three studies), "articulation” (one study), "choices” (one study), “enrichment" (two studies), "culture" (one study), "experience” (one study), “conciliation", "strategies" (one study), "dichotomy" (one study, and "responsibility" (one study). Twenty-two (14.4\%) studies applied work/career/employment-family/nonwork/life/care terminology in general without combining them with any word referring to their linkage or interface. Studies with a major focus on work-family policies used "workfamily/life" or "family-friendly policies" (five studies), "initiatives" (two studies), "benefit" (two studies), "programs" (one study), “conditions" (one study), and "careers" (one study). Eight studies used no specific terminology to refer to the work-family.

Theory. Eighty-four (55.2\%) studies did not report any theory guiding their research. Fourteen (9.2\%) studies used work-family border (Clark, 2000), boundary (Ashforth et al., 2000; Kreiner, Hollensbe, \& Sheep, 2009; Nippert-Eng, 1996) and spillover (e.g., Grzywacz \& Marks, 2000) theories; eight (5.2\%) studies adopted feminist theories (e.g., Mirchandani, 1998; Rothman, 1994; Smith, 1987), gender-related (e.g., Acker, 1992;West \& Zimmerman, 2002), expansionist (e.g., Zimmerman, Haddock, Current, \& Ziemba, 2003), Bourdieuian approach (Bourdieu 1987; Bourdieu 1990) and ideal worker (Bailyn, 1993; Williams, 2000) theories; seven (4.6\%) studies were based on role-related and identity-related theories; five studies (3.2\%) adopted structuration theory (Giddens, 1984); and three studies were based on the resource-based view of a firm (e.g., Wright, Dunford, \& Snell, 2001) and the conservation of resources (Hobfoll, 1989). The remaining thirty-one (20.39\%) studies employed scattered theories such as kaleidoscope career model theory (Mainiero \& Sullivan, 2005), domain theory (Layder, 1997), human capital theory (Becker, 1964), institutional theory (DiMaggio \& Powell, 1983; Meyer \& Rowan, 1977), worker agency and free will (Taylor 1911), family 
time economies framework (Maher et al., 2008) and the theory of the greedy organization (Franzway, 2001).

\section{Question 2. What Qualitative Methodologies and Methods are Adopted by Work-}

\section{Family Researchers in the Management Field?}

Subjectivity statement. Qualitative researchers need to be self-reflexive before and during fieldwork, constantly documenting their biases, motivations, and changes in directions (Lincoln \& Guba, 1985). "The process of reflecting crucially on the self as researcher, the human as instrument" (Denzin \& Lincoln, 2000, p. 210) is often referred to as reflexivity or subjectivity. Although qualitative researchers are expected to provide a statement reflecting their subjectivity, our review showed that 147 studies (97\%) in this review did not include subjectivity statements.

Research approach. Among the 152 studies, 102 studies (67.1\%) utilized a generic qualitative approach. By generic, we refer to a basic qualitative research study that aims to "understand how people make sense of their lives and their experiences" (Merriam, 2009, p. 23) without a specific design for narrative analysis, grounded theory, case study, phenomenology, ethnography (Merriam, 2009) or other qualitative research approaches. Thirty-one (20.3\%) studies employed non-generic types of qualitative methodologies. Thirteen $(8.5 \%)$ studies used a case study approach. Other approaches included ethnography and field studies (seven studies), phenomenology (seven studies), grounded theory (two studies), narrative approach (one study), and discourse analysis (one study). Nineteen studies did not mention anything about their methodology or research approach, the majority of which only mentioned that they conducted interviews to collect data.

Research participants. Forty-six (30.2\%) studies involved only female participants, and fourteen (9.09\%) involved only male participants. Eighty-five (55.92\%) studies had both male and female participants. Seven (4.6\%) articles did not specify participants' gender. The 
studies included in the review had participants who held positions as executives, entrepreneurs or managers, and professionals working across multiple industries such as health, law, IT, academia, finance, and the service sector.

Data collection. One hundred-fifteen (75.6\%) studies conducted face-to-face or telephone interviews (68.45\%) and focus group interviews (7.2\%) to collect data. Five $(4.54 \%)$ studies collected data via written responses from surveys. Eighteen (11.8\%) studies used interviews in addition to complementary data collection methods including participant observation, shadowing, documents, open-ended surveys, or diaries. Four (2.6\%) studies solely relied on documents to collect their data.

\section{Data analysis}

Data analysis techniques. Qualitative data analysis is "a process of making sense out of data" (Merriam, 2009, p. 193). In this process, researchers often utilize various strategies and techniques to interpret and report the meaning of the data by developing categories and themes or other class taxonomies (Merriam, 2009). In our review, thirty-three (30\%) studies employed grounded theory and constant comparative techniques to analyse data. Forty (36.36\%) studies used content analysis, thematic analysis, or coding. The remaining studies used discourse analysis ( 5 studies) and interpretive methods (5 studies). Three studies used Gregory and Milner's (2009) framework of opportunity structures, Miles and Huberman's (1994) interactive model, and Eisenhardt's (1989) proposed data analysis methods. Twentyfour $(21.81 \%)$ studies did not provide information in regard to their data analysis technique.

Data analysis software. There are several computer software programs designed to help qualitative researchers store, retrieve, and analyse qualitative data (Merriam, 2009). One hundred and ten $(72.3 \%)$ studies did not use any software to analyse qualitative data or did not mention it. Twenty-eight (18.4\%) studies used NVivo, eight (5.2\%) used ATLAS.ti, and six used MAXQDA, NUD*IST, or Excel to facilitate qualitative data analysis. 
Data analysis steps. Data analysis processes can involve several steps through which researchers "arrange the material into a narrative account of the findings" (Merriam, 2009, p. 193). Eighty-two (54\%) studies described their data analysis steps, and seventy (46\%) did not mention the phases of their data analysis. Only eighteen (11.8\%) studies provided one or more examples from the process of data analysis to illustrate how raw data was turned into findings.

\section{Question 3. What Do We Know Based on Qualitative Work-Family Studies in}

\section{the Management Field?}

We used content analysis (Neuendorf, 2002) to synthesize the findings of the qualitative work-family papers involved in this review. To do so, we read each paper and took notes in regard to the major findings, thus resulting in sixty-five pages of text. Next, we read the findings and categorized them according to keywords and focus, and referred to papers in cases wherein we needed to further contextualize our notes. In some cases, a single paper was included in more than one category because it discussed findings on more than one topic. Finally, we identified six major themes among the findings of the reviewed studies: parenthood, gender differences, cultural differences, family-friendly policies and nontraditional work arrangements, coping strategies/solutions, and under-studied populations. We acknowledge that these themes might overlap and have only separated them for the purpose of clarity. Below, we present each theme with reference to those papers that touched on them.

Parenthood. The effect of parental status and identity on how employees combine their work and family lives were major findings of various papers (e.g. Loscocco, 1997; Ladge, Clair, \& Greenberg, 2012). Parents were typically pressed for time (Pedersen \& Lewis, 2012) and believed that organizational policies related to parenthood were still traditional and gendered (e.g., Blain, 1993; Gherardi, 2015; Hestbaek, 1998; Lewis \& 
Smithson, 2001) not subject to significant improvements over the years (Weststar, 2012). A number of studies (e.g., Dean, 2007) reported that working parents received minimal support from their employers (George, Vickers, Wilkes, \& Barton, 2008) and felt powerless in accommodating work and family lives simultaneously. In occupations wherein flexibility was in place (e.g., in academia), parents still struggled to manage domestic, caring, and professional responsibilities (Rafnsdóttir \& Heijstra, 2013). Academics shared stories about delaying giving birth to children until after tenure (Solomon, 2011).

Specific to mothers were dilemmas related to transition to motherhood (Singley \& Hynes, 2005), sustaining engagement with work (Millar \& Ridge, 2009), and returning to work after taking maternity leave (Golden \& Geisler, 2007). Mothers reported that children were their priority but that they also cared a lot about their careers (Ridge, 2007). Many mothers managed to retain their work status along with motherhood; some found solutions such as opting for a flexible, part-time job (Grant-Vallone \& Ensher, 2011; Wharton, 1994), or self-employment (Carrigan \& Duberley, 2013). However, unlike what some fathers believed, flexible work was not easily available for mothers (Gatrell, Burnett, Cooper, \& Sparrow, 2014) and was not adequate for accommodating mothers' work-family issues (Wharton, 1994). Although maternal competencies were said to complement work competencies (e.g., Leberman \& Palmer, 2009; Leberman \& LaVoi, 2011), some mothers hid their motherhood to secure their organizational image (Cahusac \& Kanji, 2014). In general, mothers indicated they would plan their work schedules based on the contingencies of their children when possible (e.g., school time). Single mothers and mothers whose children had special needs (e.g. were disabled) experienced more challenges and did not receive additional support (Bakker \& Karsten, 2013; Cunningham-Burley, Backett-Milburn, \& Kemmer, 2006; Lewis et al., 1999). 
An emergent theme in studies focusing on work-family among parents was that women are reinterpreting the available mother notion (Nadim, 2014), re-thinking childcare and defining it as a 'socialized activity' (Uttal, 1996). They argued that mothers are responsible for children's wellbeing and in charge of childcare but can delegate it to others. Despite the critiques working mothers received, they believed that their employment not only enriched their lives, but also that of their children (Motro, \& Vanneman, 2015).

Fathers, in contrast, argued that the traditional roles and images of fathers have changed in recent decades (DeLong \& DeLong, 1992; Humberd, Ladge, \& Harrington, 2015; Humberd, Ladge, \& Harrington, 2015); therefore, upholding traditional fathering practices would not allow couples to balance their work and family spheres (Eräranta \& Moisander, 2011). In the cases highlighted in these studies, fathers reported feeling invisible (Burnett, Gatrell, Cooper, \& Sparrow, 2013), being marginalized by family-friendly policies and beneift packages (Gatrell et al., 2014, Blumen, 2015), and believing that workplace policies were contradictory to changes in fatherhood norms (Damaske, Ecklund, Lincoln, \& White, 2014). Fathers believed that organizations expected men to work late and embrace long hours; expectations which deprived them of time spent with their children (Root \& Wooten, 2008).

Gender differences. Findings from these qualitative work-family studies confirmed that in the majority of cases, gender differences were present in the accommodation of workfamily needs (e.g., Burnett et al., 2013; Emslie \& Hunt, 2009; Fujimoto, Azmat, \& Haertel, 2013; Loscocco, 1997; Perrons, 2003). Examples of such differences include forgoing individual needs (Guendouzi, 2006), gendered time use (Rafnsdóttir \& Heijstra, 2013), gendered family structure (Stalp \& Conti, 2011), gendered household labour, parenting and caring roles (Crompton \& Lyonette, 2011; Hilbrecht, Shaw, Johnson, \& Andrey, 2008; Lowson \& Arber, 2014; Windebank, 2001), gendered employment relations (Hantrais \& 
Ackers, 2005; Turbine \& Riach, 2012) and gendered family-friendly policies/programs (McDonald et al., 2007; Root \& Wooten, 2008). However, in a few studies, gender did not seem to have any significant effect (Vázquez-Carrasco, López-Pérez, \& Centeno, 2012; Weststar, 2012).

Cultural differences. A few studies highlighted work-family experiences of participants who came from different cultures and showed that cultural and national contexts influenced employee expectations of work-family support and the adoption of family-friendly policies. For example, gender socialization played a major role in integrating work and family in the Asian countries. Although the maternity and paternity leave policies were in place, employees tended to "shy away from availing the facility as it [was] perceived more as a woman's domain" (Chandra, 2012, p. 1046). Since coping with WFC was perceived a personal responsibility from the Eastern perspectives, many individuals chose to outsource the domestic work or rely on assistance from parents and in-laws to deal with work-family issues (Chandra, 2012; Phang \& Lee, 2009). Employees of an Asian collectivist culture tended to place organizational goals over their personal goals when deciding not to use family-friendly programs their employer offered (Kim \& Faerman, 2013).

In contrast to the Asian cultures, in Europe, valuing individual responsibility, independence and self-reliance, created a sense of entitlement to State and employer workfamily support for young women and men (Lewis \& Smithson, 2001). Swedish and Norwegian participants both received better support and had higher expectations of familyfriendly policies (e.g., flexible work hours) provided by their government and employers as a result of welfare state equality contracts. Furthermore, social contracts assumed both women and men to be carers and paid workers; thus, the sense of entitlement to support was strong.

In Ireland, Portugal and the UK expectations for support were low as traditional gender equality contracts underpinned welfare systems (Lewis \& Smithson, 2001). Collective 
bargaining and union contracts influenced work-family policies and practices in Australia and the US. In Australia, employees had greater access to standardized annual leave and unpaid parental leave entitlements because of having a centralized industrial relations system (Berg et al., 2013). However, in the US, instead of national union standards, a fragmented and local approach to union contract bargaining, determined work-family policies and practices (Berg et al., 2013).

\section{Family-friendly policies and non-traditional work arrangements. Receiving} support from various sources — specifically from organizations and families—played a major role in helping employees balance their work and family commitments (Grady \& McCarthy, 2008; Phang \& Lee, 2009; Root \& Young, 2011). However, many findings emphasized the important role of supervisor support and the perceived absence of it in many organizations (Kim \& Faerman, 2013; George et al., 2008).

Employees asserted that to accommodate all employees' work-family needs, HR departments should provide tailored support (Kollinger-Santer \& Fischlmayr, 2013; Fischlmayr \& Kollinger, 2010). In cases wherein organizations provided one-size-fits-all support, different unions elicited different outcomes because the support in place did not always solve employees' work-family issues (Ravenswood \& Markey, 2011). Furthermore, it is worth highlighting that organizational support was effective mainly when the management and organizational culture favoured it (Galea, Houkes, \& De Rijk, 2014; Secret \& Swanberg, 2008); otherwise, acquiring support (e.g., job sharing or flexible work) could be perceived as negative (McDonald, Pini, \& Bradley, 2007).

Most of the discourse on findings associated with family-friendly policies centred on flexibility and flexible time use. Several studies emphasized that organizations must recognize the need for — and critical role of — employees' preferences for flexibility (George et al., 2008; Lewis et al., 2000; Lo, 2003; Secret \& Swanberg, 2008), specifically for women 
(Loscocco, 1997), parents (Grant-Vallone \& Ensher, 2011), and those with extended domestic responsibilities (Gatrell et al., 2014). Employees perceived flexible work arrangements as positive in that flexibility helped improve their quality of life (Hilbrecht et al., 2008). When flexibility was not in place, informal options were used, e.g., getting help from co-workers to cover employee absenteesim (Root \& Wooten, 2008).

Findings showed that placing and maintaining organizational policies for flexitime is not easy (Berg, Kossek, Baird, \& Block, 2013) and thus requires continuous management support (Galea et al., 2014; Gatrell et al., 2014). However, in studies wherein participants enjoyed some degree of flexibility, it was considered "double-edged" (Pedersen \& Lewis, 2012). On the one hand, there was a need for flexible time to accommodate work-family needs; on the other hand, there was a desire for structure (Fonner \& Stache, 2012). In some cases, employees' WFC increased when high levels of flexibility were in place (Blair-Loy, 2009). Focusing on women in academia, Rafnsdóttir and Heijstra (2013) found that flexibility, together with gendered time use, might lead to the reproduction of traditional power dynamics between men and women. Such dual effects were the basis for critiques of workplace flexibility (Bourne \& Forman, 2014) and discussions on the lack of consistency among scholarly findings related to the ways in which flexibility contributes to work-family (Matthews, Booth, Taylor, \& Martin, 2011). A lack of organizational policies to support employees' work-family needs was also found to result in negative outcomes, including employee turnover intentions (Skinner, Elton, Auer, \& Pocock, 2014).

Among other non-traditional work arrangements were virtual, night shift, part-time, and contract work. Virtual workers made sure they had boundaries between their work and family lives (Mirchandani, 1999); those who did not have clear work-family boundaries found themselves in a state of "liminality" resulting from simultaneous involvement with personal and professional roles (Di Domenico, Daniel, \& Nunan, 2014). Shift workers- 
particularly parents - found it difficult to work at night and juggle multiple responsibilities. Father shift workers had limited opportunities to become involved in their children's activities (Root \& Wooten, 2008), and mother night shift workers had to plan very carefully to accomplish their daily routines at home (Lowson \& Arber, 2014).

Employees with work-family issues reported the desire for part-time work (Firmin \& Bailey, 2008). Part-time and job-sharing opportunities were supported by some organizations; however, in some cases, these options were perceived as negative (McDonald et al., 2007) and career-limiting (Crompton \& Lyonette, 2011). Female employees with extended family commitments found part-time work to be a solution that helped them secure their presence at the workplace (Grant-Vallone \& Ensher, 2011; Maher, 2013). Finally, contract work was considered to have advantages, such as allowing for flexible time and place of work, and disadvantages such as requirements for extended time allocation and flexibility when not desired (Suess \& Sayah, 2013). Contract workers used multiple ICT-mediated strategies to maintain their preferred WFI (Sayah, 2013).

There were also concerns about the difficulty of measuring work-family support within organizations and gauging how such support contributes to the organizational bottom line (Bardoel, Cieri, \& Mayson, 2008). Managers were perceived to be interested in tangible economic returns resulting from their support of employees' work-family needs (Lewis \& Smithson, 2001). Family support and supportive social networks (O’Ryan \& McFarland, 2010) were shown to help employees manage their WFI and improve their wellbeing.

Studies emphasized that for family-friendly policies to be effective, such policies must be added to the agendas of organizations, unions, and governments (Hantrais \& Ackers, 2005). For example, family support agencies might account for the health, care, and support needs of families with various demands, or recruit work-family advocates to support and disseminate such a mindset within organizations (Secret \& Swanberg, 2008). Otherwise, 
family-friendly policies will only serve specific groups instead of the majority (Dean, 2007). Unions were shown to play a positive role in the provision of family-friendly policies by employers (Ravenswood \& Markey, 2011).

Coping strategies/solutions. Despite the challenges and limitations in both work and family spheres, individuals managed to adopt strategies with which to maintain a balance between the two spheres and make some trade-offs to do so (Jackson \& Scharman, 2002). Examples of strategies adopted to make this happen were planfulness (O’Ryan \& McFarland, 2010), role-cycling (Wiersma, 1994), time management (Sav, Harris, \& Sebar, 2014), scaling back (Becker \& Moen, 1999), blocking out time, and time shifting of obligations (Moen, Lam, Ammons, \& Kelly, 2013). However, women were shown to have a limited choice of strategies due to gender differences and extended domestic responsibilities (Cahusac \& Kanji, 2014). Some studies found that personal strategies, such as time management, tend to be more effective than the family-friendly policies practiced by employees' immediate organizations (Sav et al., 2014).

Under-studied populations. Low-income workers, low-profile occupations, families with special needs children, and minorities were among the major under-studied populations examined by qualitative work-family researchers. Common findings across studies were the consistent lack of recognition and support, and the additional pressure that minority populations experienced. For example, low-income workers (part-time shop assistants and retail food employees) strived to maximize their control over work time to ensure that care responsibilities could be prioritized due to their limited access to childcare, flexible work arrangements, and mobility opportunities (Backett-Milburn, Airey, McKie, Hogg, 2008; McKie, Hogg, Airey, Backett-Milburn, \& Rew, 2009; Weigt \& Solomon, 2008). Parents of special needs children sought ways to prioritize family over work and avoid long work hours, but could not locate policies and procedures (Matthews et al., 2011) or informal flexibility 
and support that could help cope with their caring responsibilities (George et al., 2008; Lewis et al. 2000).

Ethnic minority women experienced additional demands above family responsibilities, specifically when they were actively engaged with their community and culture and wished to practice their religion (Kamenou, 2008). High work expectations of individuals with low-profile occupations (bus drivers and mineworkers) limited their ability to dedicate enough time and energy to non-work activities (Hughes \& Bozionelos, 2007; Jacobs, Mostert, \& Pienaar, 2008). Women engineers working in a male-dominated industry found little support available to those who desired to integrate work with caring roles and leisure activities (Watt, 2009).Gay and lesbian couples experienced a lack of recognition in the workplace and responded to such challenge by trying to be planful and developing supportive relationships with co-workers (O'Ryan \& McFarland, 2010). Similarly, Australian Muslim men proactively prevented conflict by openly discussing their religious obligations with their employers. However, some resisted taking proactive actions due to having perceptions of discrimination or fear of reducing employment opportunities (Sav et al., 2014).

\section{Question 4. How Do Findings of Qualitative Work-Family Studies in the}

\section{Management Field Compare with that of Quantitative Studies and What are Their}

\section{Theoretical Contributions?}

We compared findings from our review of qualitative studies on work-family (hereinafter referred to as qualitative findings) with the findings of published quantitative review or meta-analysis studies (hereinafter referred to as quantitative findings). Below, we present our insights on the important ways in which qualitative findings compare to that of quantitative findings.

Flexible work arrangements. Based on quantitative findings, flexible work arrangements made small contributions to diminishing work-family tensions. For example, 
Mesmer-Magnus (2006) found little effect of any component of a family-friendly work environment (i.e., offering work-family programs and policies, and having a family-friendly culture) on decreasing WFC. Similarly, Allen et al.'s (2013) analysis of studies that had used clear directional measures of WFC (work-interference-with-family (WIF) and familyinterference-with-work (FIW)) found a small effect size $(\mathrm{r}=-.08)$ for telecommuting practices (i.e., involving some degree of flexible schedule, wherein the tasks are completed during nonstandard work hours) in reducing the WIF and a nonsignificant effect size of -.01 for FIW.

Qualitative findings suggested possible reasons behind the small effect of flexible work arrangements. For example, the lived experiences of academics and entrepreneurs who had flexible schedules showed that flexible work was, in fact, a double-edged sword characterized by both advantages and disadvantages (Rafnsdóttir \& Heijstra, 2013; Di Domenico et al., 2014). Also, the accounts of part-time workers showed that in reality working part-time involved a hidden stressor, which was risking future career opportunities (Crompton \& Lyonette, 2011).

Support. Qualitative findings supplemented quantitative findings on the critical impact of receiving support from the organization, supervisor, and coworker in managing work and family demands. A meta-analytic review of quantitative results has reported a moderate relationships between WFC and organization support $(p=-0.30)$, a small negative relationship between WFC and supervisor support $(p=-0.22)$, and coworker support ( $p=-$ 0.25) (Michel et al., 2011). Correspondingly, qualitative findings highlighted the significant roles of human resource departments, supervisors, coworkers, and unions in resolving workfamily issues (e.g., Galea et al., 2014; Secret \& Swanberg, 2008).

Gender and parenthood. Both qualitative and quantitative findings agreed that gender and parental status influenced the WFI. Quantitative findings have found a 
moderating effect for gender and parenthood in the relationships between the WFI and its predictors and outcomes (e.g., Byron, 2005; Michel et al., 2011; Shockley \& Singla, 2011). Qualitative findings completed the quantitative findings by giving a profound sense of the realities of working parents' lives and the frustrations and challenges they face (described in the parenthood theme).

Balanced attitude towards the WFI. Quantitative research on work-family has been particularly likely to investigate either a negative or a positive relationship between work and family roles (Allen et al., 2012). However, the negative and positive orientations toward the impact of work and family on one another appear to be less amenable to qualitative research. Qualitative researchers have studied work-family with less tendency to make assumptions about the negative or positive nature of work and family interdependencies. More than half of the qualitative studies (64.4\%) targeted the overall experiences of work-family, which fitted in the middle of a continuum of positive and negative perceptions (e.g., Poppleton et al., 2008). Among the 152 studies we reviewed, only fourteen (9.2\%) qualitative studies used the term conflict; but over 1200 quantitative studies reviewed in nine existing meta-analyses (Allen et al., 2012; Amstad et al., 2011; Byron, 2005; Ford, Heinen, \& Langkamer, 2007; Kossek et al., 2011; Mesmer-Magnus \& Viswesvaran, 2005; Mesmer-Magnus \& Viswesvaran, 2006; Michel et al., 2009; Michel et al., 2011) used WFC terminology, which refers to negative effects of work and family on one another.

Theoretical lens. Quantitative studies on work-family have examined the relationships between work and family through a few dominant theoretical lenses. Previous reviews and meta-analyses have not reported a list of theories used in quantitative studies to enable us to make an exact comparison. However, the authors of earlier reviews have referred to the role strain theory (Kahn et al., 1964) and expansion theory (Marks, 1977; Sieber, 1974) as the two prominent theoretical umbrellas for much of the quantitative work-family literature 
(Allen et al., 2012; Casper et al., 2007; Eby, 2005; McNall, Nicklin, Masuda, 2009; Michel et al., 2009). In comparison, in cases where using a theory was applicable, qualitative studies used a wider range of theories.

One explanation for the use of diverse theories in qualitative studies on work-family is the design of qualitative inquiries that focus on inductive analysis of social phenomena rather than testing theory through hypotheses (Merriam, 2009). Qualitative researchers look for possible theories that fit findings of their studies and situate their results in the literature, pointing out to how their data extend or contradict previous theories (Merriam, 2009). For example, Burchielli et al. (2008) argued that the greedy organization theory (Franzway, 2001) offered a useful metaphor they borrowed to explain their findings regarding the role of organizations in creating extra demands interfering with workers' work-family balance.

Using diverse theories in qualitative work-family research enables researchers to explain aspects of work-family that were difficult to explore through the quantitative approach. For example, drawing from structuration theory (Giddens, 1984), Tracy and Rivera (2010) described how the process of talking revealed and produced scripts about gender, workplace, and work-family intersections. The focus on junctures in talking (e.g., "umms," “ahhs," pauses, and talk repairs) showed that managers increased blunders when discussing gender roles and work-life issues. The unrehearsed talks were the key to uncovering the enduring scripts that are not typically articulated. In another study, the Foucauldian theory (Dean, 1999; Foucault, 1985) was used to clarify how traditional fatherhood discourses interfered with work and family balance (Eräranta \& Moisander, 2011). Observed in the texts published by government agencies, were the general policies that organized male parenting in two particular ways of 'manly' and 'involved' fathering. The focus on government reinforced discourses and revealed enduring cultural patterns and practices that constituted the known forms of fathering. 
The US dominance. Qualitative work-family research was less tightly connected to the US as compared to the quantitative studies. Among the 142 qualitative articles that reported the country where their study was conducted (out of the 152 we reviewed), $70 \%$ included no participants from the US. Casper et al.'s (2007) review of work-family research methodologies, which included only three qualitative studies, showed that 75\% (a total of 200) of the empirical research was distinctively conducted in the US.

Quantitative studies have been ill-fitted to examine how individual's national or subgroup culture influences her/his reaction to work and family (Parasuraman \& Greenhaus, 2002). Previous reviews on quantitative empirical research have signalized a gap in our understanding of work-family in other cultures (Casper et al., 2007; Kossek et al., 2011; Özbilgin et al., 2011). However, as described in this paper, qualitative findings uncovered how the cultural and national context influenced employee expectations of work-family support and the practice of family-friendly policies. As described in the findings, qualitative research identified gender socialization (e.g. Chandra, 2012), cultural values (e.g. Kim \& Faerman, 2013), and welfare state equality contracts (e.g. Lewis \& Smithson, 2001) to be the most salient factors shaping expectations of work-family support among different cultures.

\section{Discussion and Pathways for Future Research}

In this paper, we argued that the current literature on work-family has favoured quantitative methods and overlooked qualitative research approaches. However, qualitative research can contribute to an exploration of perspectives that quantitative methodologies might otherwise fail to discover (Gephart, 2004). We conducted a review aiming to synthesize qualitative studies on work-family published in all major journals that publish management-related studies and are indexed in SSCI without any time limitation. We meant to provide a comprehensive profile of the studies included in the review. Below, we highlight and discuss the major conclusions of the review. 


\section{Limited Number of Qualitative Endeavours on Work-Family}

Our review covered a number of different perspectives on work-family (e.g., WFC, work-family spillover, work-family enrichment, work-family boundary, and work-family balance) and family-friendly policies. The review included 152 studies, which was a small number given the unlimited time span, the comprehensive keyword search (approximately 52 keywords) and the number of disciplines we included (seven). In addition, this review was the first review that had a major focus on qualitative work-family studies. More than twenty review and meta-analysis published on the topic (some of which including over 200 studies) have either excluded or included a few qualitative studies. Work-family researchers may neglect qualitative approaches to management research because of a lack of qualitative research training available at business schools, especially in the US (Gephart, 2004). Many top-ranked business schools in the US only embrace quantitative approaches and do not include qualitative research methodology courses in their curriculum for graduate students (Navarro, 2008). The increasing number of qualitative publications surfacing in recent years, as shown previously, might be a sign of increased interest in qualitative approaches; however, there is still much room for improvement.

The results showed that unlike quantitative studies, the qualitative studies based in the UK or Europe outnumbered those conducted in the US context. The fact that the UK and the European business schools promote qualitative approaches (Silva \& Ramos, 2013) might account for the higher number of publications involving participants from the UK or Europe, despite the higher number of US-based quantitative publications on the same topic, as shown in previous reviews (e.g., Casper et al., 2007). Many regions did not produce qualitative contributions to the work-family literature; for instance, our search did not yield studies involving Middle Eastern participants. This gap might be attributable to language barriers, 
especially in regard to qualitative research methodologies that require an extended use of descriptive language.

\section{Providing Findings Worth Further Attention}

A synthesis of the findings reported in the papers reviewed herein revealed that qualitative studies produced findings worth more attention in the work-family field. Qualitative findings challenge the widespread rhetoric of the prevalence and benefits of family-friendly policies and non-traditional work arrangements, especially at the individual level. Qualitative research reported not only a perceived lack of access to family-friendly policies but also realities about the failure of non-traditional work arrangements in improving work-family. As Allen (2015) argued, the field needs to re-conceptualize flexible work solutions by taking their potential drawbacks into consideration. This review's specifications of advantages and disadvantages of family-friendly policies and non-traditional work arrangements yield a venue for researchers to develop theoretical models and practical solutions and policies attending to both benefits and drawbacks.

Qualitative findings remind us that the complexities of work-family realities cannot be fully understood through binary thinking and dichotomous terms such as conflict or enrichment. Employees' work-family experiences as reported in qualitative findings fit in a continuum of positive and negative perceptions. Thus, a holistic theory free from presuppositions about the nature of work and family interdependencies or a comprehensive model combining prior perspectives can provide an improved explanation of the work-family phenomenon.

Qualitative research on populations outside the US informs work-family scholarship on cross-cultural similarities and differences, and the impact of national context on the meaning of work-family policies and support for individuals. In addition to cultural differences, other demographic or ethnic varieties among employees' groups have been 
studied by qualitative researchers. A genuine work-family theory may emerge by incorporating factors related to the experiences of work-family individuals who belong to diverse cultures and/or groups.

\section{Convergent Foci}

More than half of the studies considered in this review focused on the experiences, challenges, and issues participants faced when juggling work and family. This focus is justifiable due to the nature of qualitative inquiry, which is mainly concerned with individual accounts and experiences (Merriam, 2009). However, there is room for future qualitative researchers to espouse a more divergent focus. For example, qualitative work-family scholars should look at different layers of interaction between work and family, explore the impact of cultural differences on work-family, and consider non-nuclear/non-traditional families. Alternatively, scholars might adopt a historical attitude toward work-family and its development over time in different contexts and societies. Conducting studies with diverse orientations will allow researchers to benefit from the richness of naturalistic inquiry and explore more complex phenomena.

Qualitative research can make a clear contribution to resolving the criticism of workfamily research for weak theory (Casper et al., 2007). Qualitative methodologies offer the right tools to develop theoretical conceptualizations of the work-family phenomenon. For example, 'work/family border theory' was introduced as a result of a qualitative inquiry (Clark, 2000). Further, qualitative research can contribute to the work-family literature by focusing on aspects of work-family that are difficult to explore through quantitative investigations such as work-family dynamics over time and the non-linear relationships between work and family domains (Allen, 2012). In addition, qualitative research can address the gap in the literature for understanding the processes involved in prioritizing work-family activities (Parasuraman \& Greenhaus, 2002). 


\section{Loose Use of the WFI Terminology}

"Work-family/life balance" is the most commonly adopted term in discussions of the WFI; accordingly, this term was used in more than thirty-five percent of the studies included in this review. Despite the prevalence of this terminology, it lacks a sufficient theoretical basis (Clark, 2000; Greenhaus et al., 2003). Some studies did not provide a clear definition of the WFI terminology they used; however, the definition and conceptualization of the WFI affects the whole research process and its findings. For example, the use of the term "workfamily conflict" carries with it some negative connotations; however, the reverse is true for the use of terminologies with a positive flavour such as "work-family enrichment" or "enhancement". In cases wherein the study does not seek to build theoretical arguments, it might be helpful for the work-family qualitative researchers to adopt a theoretical framework that gives their definitions and terminologies a solid background. Approximately half of the studies involved in this review were theory-based, but it is beyond our capacity to argue whether the remaining studies were eligible for a deepening of their theoretical arguments.

\section{Neglecting the Variety of Qualitative Research Approaches}

Qualitative research encompasses a variety of types including generic, grounded theory, case study, ethnography, phenomenology, and narrative analysis (Merriam, 2009). The choice of qualitative research design depends primarily on the nature of the qualitative data; however, different methodologies address different types of questions and accordingly yield different types of results.

In this review, more than sixty-five percent of the studies adopted a generic qualitative method. Moreover, the data collection methods were limited to qualitative interviewing (face-to-face, phone, or focus group). For example, participant observation and life history interviewing were rarely used as prominent methods of date collection. One reason for the absence of diverse research methodologies and data collection methods could 
be the time-consuming nature of such techniques. Work-family researchers may have faced problems with getting access to participants who were willing to spare the time to participate in extensive data collection beyond a 1-2 hour interview.

It thus appears that qualitative work-family researchers in the management field need to take into account the untapped potential of multiple types of qualitative research to add to the current literature. For instance, in addition to adopting a generic approach, work-family researchers could use phenomenology approach that seeks to examine the lived experiences of a phenomenon (Moustakas, 1994). This approach will allow the work-family researchers to dig the participants' experiences of a phenomenon and come up with a universal essence (Moustakas, 1994). Those studying the effectiveness of a family-friendly policy might benefit from adopting a case-study approach that allows for gaining a detailed and holistic understanding of the case/s under study (Stake, 1995). Grounded theory, might also serve as an appropriate approach for studying work-family areas that have not been theoretically explored.

It appears that some scholars do not find it necessary to define the type of qualitative methodology they adopt and perceive that collecting qualitative data itself sufficiently explains the methodology of the study. This trend signifies that educational bodies - and business schools in particular-need to invest in educating future researchers on the specificities of qualitative research. Such a strategy might be made possible via joint collaborations with other schools and departments, such as sociology or health, which are already active in qualitative research (Jensen \& Allen, 1996).

\section{Quantitative Attitude towards Qualitative Research}

During the review process, we noticed that some studies adopted a quantitative attitude despite reporting qualitative research. This disjuncture might be attributable to insufficient training in qualitative research reporting or the quantitative orientation of the 
authors, journal reviewers, or editors. For example, in a few cases, research questions were provided under the title "measures," a term that reveals a quantitative mind-set. In some other cases, when researchers sought to emphasize the "trustworthiness" of their data, they used the terms "validity" and "reliability," which are again terms borrowed from a quantitative approach. Another example is the number of participants. As discussed extensively in the qualitative research literature, qualitative research does not seek to generalize its findings; instead, it seeks to gain in-depth data from participants (Lincoln \& Guba, 1985). Therefore, it is not necessary for qualitative researchers to have an extremely large number of participants as it might negatively affect the depth of the data collected.

\section{Insufficient Details about Research Methods}

The nature of qualitative research requires that the researcher provide rich descriptions to the reader. When describing participants, five studies did not provide gender distributions, which is a major shortcoming. Concerns over insufficient descriptions are true of data collection processes as well. Qualitative work-family researchers work with human subjects in the majority of cases, and as such, are expected to mention whether they acquired Research Ethics approval and obtained consent from participants; however, more than half of the studies reviewed herein did not refer to these two processes. Proceeding to the next step in research — that is, data analysis - more than one-fourth of the reviewed studies failed to mention their data analysis methods. Another shortcoming of the data analysis process was the failure among researchers to provide a description of the data analysis steps; this was the case for more than forty percent of the studies reviewed herein. Future work-family researchers need to be more concerned with providing such descriptions as this will add much to the rigor of the qualitative study.

As mentioned earlier, qualitative researchers are more personally involved in their studies; thus one cannot separate a qualitative researcher from his/her study, interpretations, 
or findings. Qualitative researchers need to describe, no matter how briefly, the ways in which they relate to their study; in other words, they need to provide a subjectivity statement. For example, if a scholar who has a child with autism looks at the work-family experiences of working parents with an autistic child, the outcome might be slightly different from those who do not have a similar experience. Expressing such information in the published article can deepen the readers' understanding of qualitative research. In the studies we reviewed, only five papers included a subjectivity statement and described their relationship with their study.

\section{Implications and Limitations}

\section{Implications}

This study has implications both for the management field in general and work-family researchers in specific. Our review shows that the management field has yet to seize upon the potential of qualitative research. Although we appreciate the value of quantitative research, we also believe that a phenomenon is best explored when approached through both qualitative and quantitative approaches. This review showed that some studies do not provide an account of the necessary methodological elements of qualitative research. The fact that twenty-four studies failed to discuss their data analysis techniques should be a warning for the field that a more serious approach to qualitative research is necessary. Moreover, the same review can be conducted on other quantitatively well-received management topics to determine whether the issues addressed in this study are common among other qualitative studies in the field.

Work-family researchers can use the findings of this review as a guide for future research. Our synthesis of the qualitative findings offers several venues for scholars to enhance work-family theory. Cultural, ethnic, and demographic differences reported in qualitative findings call for a work-family theory that applies to more diversified employee 
groups. Qualitative findings draw the attention to a need for a holistic theory of work-family developed free from common presuppositions about the nature of work and family relationships. Finally, we showed that a variety of qualitative research methodologies have not yet been employed by management work-family researchers. This finding, together with the highlights from the status and findings of the papers reviewed herein, can function as a guiding tool for both novice and experienced qualitative researchers who intend to push the field forward.

\section{Limitations}

Our study has three major limitations. First, we excluded papers published in languages other than English. We acknowledge that this shortcoming excluded some papers that have contributed to the field. Second, we limited our search to SSCI-indexed papers and could not include all peer-reviewed journals. Third, we only searched article keywords, title, and abstracts; this practice may have led to missing papers that focused on work-family but did not use key terms in the search fields. Despite these limitations, however, we believe that this study provides a useful picture of what is going on in the work-family field regarding qualitative research and thus sheds light on this line of inquiry. 


\section{References}

Note: References marked with an asterisk indicate the studies included in this review.

*Abbott, J., \& Cieri, H.D. (2008). Influences on the provision of work-life benefits: Management and employee perspectives. Journal of Management and Organization, 14, 303-322.

*Abstein, A., \& Spieth, P. (2014). Exploring HRM meta-features that foster employees' innovative work behaviour in times of increasing work-life conflict. Creativity and Innovation Management, 23, 211-225.

*Ammons, S. K. (2013). Work-family boundary strategies: Stability and alignment between preferred and enacted boundaries. Journal of Vocational Behavior, 82, 49-58.

*Armstrong, J. (2006). Beyond 'juggling' and 'flexibility': Classed and gendered experiences of combining employment and motherhood. Sociological Research Online, 11(2).

*Ba', S. (2010). Meaning and structure in the work and family interface. Sociological Research Online, 15(3) doi:10.5153/sro.2132

*Backett-Milburn, K., Airey, L., McKie, L., \& Hogg, G. (2008). Family comes first or open all hours?: How low paid women working in food retailing manage webs of obligation at home and work. Sociological Review, 56(3), 474-496. doi:10.1111/j.1467954X.2008.00800.X

*Bakker, W., \& Karsten, L. (2013). Balancing paid work, care and leisure in post-separation households: A comparison of single parents with co-parents. Acta Sociologica, 56(2), 173-187. doi:10.1177/0001699312466178

*Baldock, J., \& Hadlow, J. (2004). Managing the family: Productivity, scheduling and the male veto. Social Policy and Administration, 38, 706-720. 
*Bardoel, E. A., Cieri, H. D., \& Mayson, S. (2008). Bridging the research-practice gap: Developing a measurement framework for work-life initiatives. Journal of Management and Organization, 14, 239-258.

*Becker, P., \& Moen, P. (1999). Scaling back: Dual-earner couples' work-family strategies. Journal of Marriage and the Family, 61(4), 995-1007. doi:10.2307/354019

*Berg, P., Kossek, E. E., Baird, M., \& Block, R. N. (2013). Collective bargaining and public policy: Pathways to work-family policy adoption in Australia and the United States. European Management Journal, 31, 495-504.

*Bjornholt, M. (2014). Changing men, changing times - fathers and sons from an experimental gender equality study. Sociological Review, 62(2), 295-315. doi:10.1111/1467-954X.12156

*Blain, J. (1993). I cant come in today, the baby has chickenpox - gender and class processes in how parents in the labor-force deal with the problem of sick children. Canadian Journal of Sociology-Cahiers Canadiens De Sociologie, 18(4), 405-429. doi: $10.2307 / 3340898$

*Blair-Loy, M. (2009). Work without end? Scheduling flexibility and work-to-family conflict among stockbrokers. Work and Occupations, 36, 279-317.

*Blumen, O. (2015). Employee benefits and high-tech fatherhood. Journal of Managerial Psychology, 30(5), 535-549. doi:10.1108/JMP-07-2013-0212

*Borve, H. E., \& Bungum, B. (2015). Norwegian working fathers in global working life. Gender Work and Organization, 22(4), 309-323. doi:10.1111/gwao.12086

*Bourne, K. A., \& Forman, P. J. (2014). Living in a culture of overwork: An ethnographic study of flexibility. Journal of Management Inquiry, 23, 68-79.

*Burchielli, R., Bartram, D., \& Thanacoody, R. (2008). Work-family balance or greedy organizations? Relations Industrielles-Industrial Relations, 63, 108-133. 
*Burnett, S. B., Gatrell, C. J., Cooper, C., \& Sparrow, P. (2013). Fathers at work: A ghost in the organizational machine. Gender, Work and Organization, 20, 632-646.

*Cahusac, E., \& Kanji, S. (2014). Giving up: How gendered organizational cultures push mothers out. Gender, Work and Organization, 21, 57-70.

*Carrigan, M., \& Duberley, J. (2013). Time triage: Exploring the temporal strategies that support entrepreneurship and motherhood. Time \& Society, 22(1), 92-118. doi:10.1177/0961463X11402314

*Chandra, V. (2012). Work-life balance: Eastern and Western perspectives. International Journal of Human Resource Management, 23, 1040-1056.

*Christopher, K. (2012). Extensive mothering employed mothers' constructions of the good mother. Gender \& Society, 26(1), 73-96. doi:10.1177/0891243211427700

*Clarke, M. (2015). Dual careers: The new norm for gen Y professionals? Career Development International, 20(6), 562-582. doi:10.1108/CDI-10-2014-0143

*Cook, L. H., \& Shinew, K. J. (2014). Leisure, work, and disability coping: "I mean, you always need that 'in' group". Leisure Sciences, 36(5), 420-438. doi:10.1080/01490400.2014.912167

*Cooke, F., \& Xiao, Y. (2014). Gender roles and organizational HR practices: The case of women's careers in accountancy and consultancy firms in China. Human Resource Management, 53, 23-44.

*Crompton, R., \& Lyonette, C. (2011). Women's career success and work-life adaptations in the accountancy and medical professions in Britain. Gender, Work and Organization, 18, 231-254.

*Cunningham-Burley, S., Backett-Milburn, K., \& Kemmer, D. (2006). Constructing health and sickness in the context of motherhood and paid work. Sociology of Health \& Illness, 28(4), 385-409. doi:10.1111/j.1467-9566.2006.00498.x 
*D'Abate, C. (2005). Working hard or hardly working: A study of individuals engaging in personal business on the job. Human Relations, 58, 1009-1032.

"Damaske, S., Ecklund, E. H., Lincoln, A. E., \& White, V. J. (2014). Male scientists' competing devotions to work and family: Changing norms in a male-dominated profession. Work and Occupations, 41, 477-507.

*Dean, H. (2007). Tipping the balance: The problematic nature of work-life balance in a lowincome neighbourhood. Journal of Social Policy, 36, 519-537.

*Delong, T., \& Delong, C. (1992). Managers as fathers - hope on the homefront. Human Resource Management, 31, 171-181.

*Di Domenico, M., Daniel, E., \& Nunan, D. (2014). 'Mental mobility' in the digital age: Entrepreneurs and the online home-based business. New Technology, Work and Employment, 29, 266-281.

*Emslie, C., \& Hunt, K. (2009). 'Live to work' or 'work to live'? A qualitative study of gender and work-life balance among men and women in mid-life. Gender, Work and Organization, 16, 151-172.

*Fincham, B. (2008). Balance is everything: Bicycle messengers, work and leisure. Sociology-the Journal of the British Sociological Association, 42(4), 618-634. doi:10.1177/0038038508091619

"Fischlmayr, I. C., \& Kollinger, I. (2010). Work-life balance: A neglected issue among Austrian female expatriates. International Journal of Human Resource Management, 21, 455-487.

"Fonner, K. L., \& Stache, L. C. (2012). All in a day's work, at home: Teleworkers' management of micro role transitions and the work-home boundary. New Technology, Work and Employment, 27, 242-257. 
*Frame, M., \& Shehan, C. (2005). The relationship between work and well-being in clergywomen: Implications for career counseling. Journal of Employment Counseling, $42,10-19$.

"Fujimoto, Y., Azmat, F., \& Haertel, C. E. J. (2013). Gender perceptions of work-life balance: Management implications for full-time employees in Australia. Australian Journal of Management, 38, 147-170.

*Furbish, D. S. (2009). Self-funded leave and life role development. Journal of Employment Counseling, 46, 38-46.

*Galea, C., Houkes, I., \& De Rijk, A. (2014). An insider's point of view: How a system of flexible working hours helps employees to strike a proper balance between work and personal life. International Journal of Human Resource Management, 25, 1090-1111.

*Gatrell, C. J., Burnett, S. B., Cooper, C. L., \& Sparrow, P. (2014). Parents, perceptions and belonging: Exploring flexible working among UK fathers and mothers. British Journal of Management, 25, 473-487.

*George, A., Vickers, M. H., Wilkes, L., \& Barton, B. (2008). Working and caring for a child with chronic illness: Barriers in achieving work-family balance. Journal of Management and Organization, 14, 59-72.

*Gherardi, S. (2015). Authoring the female entrepreneur while talking the discourse of workfamily life balance. International Small Business Journal, 33(6), 649-666. doi:10.1177/0266242614549780

*Golden, A. G. (2009). Employee families and organizations as mutually enacted environments: A sensemaking approach to work-life interrelationships. Management Communication Quarterly, 22, 385-415.

*Golden, A. G., \& Geisler, C. (2007). Work-life boundary management and the personal digital assistant. Human Relations, 60, 519-551. 
*Gordon, C. E., McMullin, J. A., \& Adams, T. L. (2015). Flexible small firms? why some small firms facilitate the use of flexible workplace policies. Canadian Journal of Sociology-Cahiers Canadiens De Sociologie, 40(1), 1-24.

*Grady, G., \& McCarthy, A. M. (2008). Work-life integration: Experiences of mid-career professional working mothers. Journal of Managerial Psychology, 23, 599-622.

*Grant, C. A., Wallace, L. M., \& Spurgeon, P. C. (2013). An exploration of the psychological factors affecting remote e-worker's job effectiveness, well-being and work-life balance. Employee Relations, 35, 527-546.

*Grant-Vallone, E. J., \& Ensher, E. A. (2011). Opting in between: Strategies used by professional women with children to balance work and family. Journal of Career Development, 38, 331-348.

*Gray, A. (2006). The time economy of parenting. Sociological Research Online, 11(3)

*Greer, C., \& Peterson, D. (2013). Balancing act? Cultural representations of work-family balance in the news media. Sociological Spectrum, 33(2), 117-135. doi:10.1080/02732173.2013.732872

*Guendouzi, J. (2006). "The guilt thing": Balancing domestic and professional roles. Journal of Marriage and Family, 68(4), 901-909. doi:10.1111/j.1741-3737.2006.00303.x

*Hantrais, L., \& Ackers, P. (2005). Women's choices in Europe: Striking the work-life balance. European Journal of Industrial Relations, 11, 197-212.

*Hashiguchi, M. (2010). Flexible working arrangements and specific training in the UK voluntary sector: A case study. Economic and Industrial Democracy, 31, 431-447.

*Hestbaek, A. (1998). Parenthood in the 1990s - tradition and modernity in the parenthood of dual-earner couples with different lifemodes. Childhood-a Global Journal of Child Research, 5(4), 463-491. doi:10.1177/0907568298005004007 
"Hilbrecht, M., Shaw, S. M., Johnson, L. C., \& Andrey, J. (2008). 'I'm home for the kids': Contradictory implications for work-life balance of teleworking mothers. New Technology, Work and Employment, 28, 130-144.

*Hilbrecht, M., Shaw, S. M., Johnson, L. C., \& Andrey, J. (2013). Remixing work, family and leisure: Teleworkers' experiences of everyday life. Gender, Work and Organization, $15,454-476$.

*Hislop, D., \& Axtell, C. (2011). Mobile phones during work and non-work time: A case study of mobile, non-managerial workers. Information and Organization, 21, 41-56.

*Hughes, J. (2013). A logical response to the demands of the labour market? Young people living alone in Australia. Current Sociology, 61(7), 966-983.

doi:10.1177/0011392113489522

*Hughes, J., \& Bozionelos, N. (2007). Work-life balance as source of job dissatisfaction and withdrawal attitudes: An exploratory study on the views of male workers. Personnel Review, 36, 145-154.

"Humberd, B., Ladge, J. J., \& Harrington, B. (2015). The "new" dad: Navigating fathering identity within organizational contexts. Journal of Business and Psychology, 30, 249266.

*Jackson, A. P., \& Scharman, J. S. (2002). Constructing family-friendly careers: Mothers' experiences. Journal of Counseling and Development, 80, 180-187.

*Jacobs, D., Mostert, K., \& Pienaar, J. (2008). The experience of work-life interaction in the Northern Cape mining industry: An exploratory study. South African Journal of Economic and Management Sciences, 11, 17-36.

*Kamenou, N. (2008). Reconsidering work-life balance debates: Challenging limited understandings of the 'life' component in the context of ethnic minority women's experiences. British Journal of Management, 19, S99-S109. 
"Kim, J. S., \& Faerman, S. R. (2013). Exploring the relationship between culture and familyfriendly programs (FFPs) in the Republic of Korea. European Management Journal, 31, 505-521.

"Kirkwood, J., \& Tootell, B. (2008). Is entrepreneurship the answer to achieving work-family balance? Journal of Management and Organization, 14, 285-302.

"Kollinger-Santer, I., \& Fischlmayr, I. C. (2013). Work life balance up in the air: Does gender make a difference between female and male international business travelers? Zeitschrift Fur Personalforschung, 27, 195-223.

"Kreiner, G. E., Hollensbe, E. C., \& Sheep, M. L. (2009). Balancing borders and bridges: Negotiating the work-home interface via boundary work tactics. Academy of Management Journal, 52, 704-730.

"Ladge, J. J., Clair, J. A., \& Greenberg, D. (2012). Cross-domain identity transition during liminal periods: Constructing multiple selves as professional and mother during pregnancy. Academy of Management Journal, 55, 1449-1471.

"Leberman, S. I., \& Palmer, F. R. (2009). Motherhood, sport leadership and domain theory: Experiences from New Zealand. Journal of Sport Management, 23, 303-334.

"Leberman, S., \& LaVoi, N. M. (2011). Juggling balls and roles, working mother-coaches in youth sport. Journal of Sport Management, 25, 474-488.

"Lee, M. D., Kossek, E. E., Hall, D. T., \& Litrico, J. (2011). Entangled strands: A process perspective on the evolution of careers in the context of personal, family, work, and community life. Human Relations, 64, 1531-1553.

"Lewis, S., \& Smithson, J. (2001). Sense of entitlement to support for the reconciliation of employment and family life. Human Relations, 54, 1455-1481. 
*Lewis, S., Kagan, C., \& Heaton, P. (2000). Managing work-family diversity for parents of disabled children: Beyond policy to practice and partnership. Personnel Review, 29, 417-430.

*Lewis, S., Kagan, C., Heaton, P., \& Cranshaw, M. (1999). Economic and psychological benefits from employment: The experiences and perspectives of mothers of disabled children. Disability \& Society, 14(4), 561-575.

*Linehan, M., \& Walsh, J. (2000). Work-family conflict and the senior female international manager. British Journal of Management, 11, S49-S58.

*Litrico, J., \& Lee, M. D. (2008). Balancing exploration and exploitation in alternative work arrangements: A multiple case study in the professional and management services industry. Journal of Organizational Behavior, 29, 995-1020.

*Lo, S. (2003). Perceptions of work-family conflict among married female professionals in Hong Kong. Personnel Review, 32, 376-390.

*Loevhoeiden, C., Yap, M. H. T., \& Ineson, E. M. (2011). Work-family conflicts and enrichment in the norwegian hotel industry. Scandinavian Journal of Hospitality and Tourism, 11(4), 457-482. doi:10.1080/15022250.2011.623856

*Loscocco, K. A. (1997). Work-family linkages among self-employed women and men. Journal of Vocational Behavior, 50, 204-226.

*Lowson, E., \& Arber, S. (2014). Preparing, working, recovering: Gendered experiences of night work among women and their families. Gender, Work and Organization, 21, 231-243.

*Maher, J. (2013). Women's care/career changes as connection and resilience: Challenging discourses of breakdown and conflict. Gender, Work and Organization, 20, 172-183. 
*Maher, J., Lindsay, J., \& Bardoel, E. A. (2010). Freeing time? the 'family time economies' of nurses. Sociology-the Journal of the British Sociological Association, 44(2), 269-287. doi:10.1177/0038038509357205

*Matthews, R. A., Booth, S. M., Taylor, C. F., \& Martin, T. (2011). A qualitative examination of the work-family interface: Parents of children with autism spectrum disorder. Journal of Vocational Behavior, 79, 625-639.

*McDonald, P., Pini, B., \& Bradley, L. (2007). Freedom or fallout in local government? How work-life culture impacts employees using flexible work practices. The International Journal of Human Resource Management, 18, 602-622.

*McDonald, P., Townsend, K., \& Wharton, A. (2013). The legitimation and reproduction of discourse-practice gaps in work-life balance. Personnel Review, 42, 205-222.

*McGowan, P., Redeker, C. L., Cooper, S. Y., \& Greenan, K. (2012). Female entrepreneurship and the management of business and domestic roles: Motivations, expectations and realities. Entrepreneurship and Regional Development, 29, 397-411.

*McGowan, R. A. (2009). Managerial discourses of work and eldercare: Reproducing, resisting, and negotiating boundaries between private and public. Culture and Organization, 15, 307-329.

"McKie, L., Hogg, G., Airey, L., Backett-Milburn, K., \& Rew, Z. (2009). Autonomy, control and job advancement the case of low paid women working in food retail. Work, Employment and Society, 23, 787-796.

*Millar, J., \& Ridge, T. (2009). Relationships of care: Working lone mothers, their children and employment sustainability. Journal of Social Policy, 38, 103-121.

*Millward, L. J. (2006). The transition to motherhood in an organizational context: An interpretative phenomenological analysis. Journal of Occupational and Organizational Psychology, 79, 315-333. 
*Mirchandani, K. (1999). Legitimizing work: Telework and the gendered reification of the work-nonwork dichotomy. Canadian Review of Sociology and Anthropology-Revue Canadienne De Sociologie Et D Anthropologie, 36(1), 87-107.

*Moen, P., Lam, J., Ammons, S., \& Kelly, E. L. (2013). Time work by overworked professionals: Strategies in response to the stress of higher status. Work and Occupations, 40, 79-114.

*Morehead, A. (2001). Synchronizing time for work and family: Preliminary insights from qualitative research with mothers. Journal of Sociology, 37(4), 355-369. doi:10.1177/144078301128756391

*Motro, J., \& Vanneman, R. (2015). The 1990s shift in the media portrayal of working mothers. Sociological Forum, 30(4), 1017-1037. doi:10.1111/socf.12206

*Nadim, M. (2014). Reinterpreting the relation between motherhood and paid work: Secondgeneration immigrant women in Norway. Sociological Review, 62(3), 494-511. doi:10.1111/1467-954X.12176

*Neiterman, E., \& Lobb, D. K. (2014). Women-centred but not women-friendly: Understanding student attrition in the Ontario midwifery education programme. Gender, Work and Organization, 21, 244-259.

*O’Neill, J. W. (2012). Using focus groups as a tool to develop a hospitality work-life research study. International Journal of Contemporary Hospitality Management, 24, 873-885.

*O'Ryan, L. W., \& McFarland, W. P. (2010). A phenomenological exploration of the experiences of dual-career lesbian and gay couples. Journal of Counseling and Development, 88, 71-79. 
*Oliver, E. A. (2012). Living flexibly? How Europe's science researchers manage mobility, fixed-term employment and life outside work. The International Journal of Human Resource Management, 23, 3856-3871.

*Ollier-Malaterre, A. (2010). Contributions of work-life and resilience initiatives to the individual/organization relationship. Human Relations, 63, 41-62.

*Pedersen, V. B., \& Lewis, S. (2012). Flexible friends? Flexible working time arrangements, blurred work-life boundaries and friendship. Work, Employment and Society, 26, 464480.

*Perlow, L. A. (1995). Putting the work back into work/family. Group and Organization Management, 20, 227-239.

*Perlow, L. A. (1998). Boundary control: The social ordering of work and family time in a high-tech corporation. Administrative Science Quarterly, 43, 328-357.

*Perrons, D. (2003). The new economy and the work-life balance: Conceptual explorations and a case study of new media. Gender Work and Organization, 10, 65-93.

*Peus, C., \& Traut-Mattausch, E. (2008). Manager and mommy? A cross-cultural comparison. Journal of Managerial Psychology, 23, 558-575.

*Phang, A.Y., \& Lee, K. H. (2009). Experience of social support among working mothers: A concept map. Journal of Employment Counseling, 46, 147-158.

*Pinto, L. H., \& Maia, H. S. (2015). Work-life interface of portuguese international business travelers. Academia-Revista Latinoamericana De Administracion, 28(2), 195-212. doi:10.1108/ARLA-05-2014-0066

*Poppleton, S., Briner, R.B., \& Kiefer, T. (2008). The roles of context and everyday experience in understanding work-non-work relationships: A qualitative diary study of white- and blue-collar workers. Journal of Occupational and Organizational Psychology, 81, 481-502. 
*Pratt, M. G., \& Rosa, J. A. (2003). Transforming work-family conflict into commitment in network marketing organizations. Academy of Management Journal, 46, 395-418.

*Radcliffe, L. S., \& Cassell, C. (2015). Flexible working, work-family conflict, and maternal gatekeeping: The daily experiences of dual-earner couples. Journal of Occupational and Organizational Psychology, 88(4), 835-855. doi:10.1111/joop.12100

*Radcliffe, L.S., \& Cassell, C. (2014). Resolving couples' work-family conflicts: The complexity of decision making and the introduction of a new framework. Human Relations, 67, 793-819.

*Rafnsdottiró, G. L., \& Heijstra, T. M. (2013). Balancing work-family life in academia: The power of time. Gender Work and Organization, 20, 283-296.

*Ranson, G. (2005). No longer "one of the boys": Negotiations with motherhood, as prospect or reality, among women in engineering. Canadian Review of Sociology and Anthropology-Revue Canadienne De Sociologie Et D Anthropologie, 42(2), 145-166.

*Ravenswood, K., \& Markey, R. (2011). The role of unions in achieving a family-friendly workplace. Journal of Industrial Relations, 53, 486-503.

*Reeve, B. H., Broom, D. H., Strazdins, L., \& Shipley, M. (2012). Regulation, managerial discretion and family-friendliness in Australia's changing industrial relations environment. Journal of Industrial Relations, 54, 57-74.

*Ridge, T. (2007). It's a family affair: Low-income children's perspectives on maternal work. Journal of Social Policy, 36, 399-416.

*Rigby, M., \& O’Brien-Smith, F. (2010). Trade union interventions in work-life balance. Work, Employment and Society, 24, 203-220.

*Root, L. S., \& Wooten, L. P. (2008). Time out for family: Shift work, fathers, and sports. Human Resource Management, 47, 481-499. 
*Root, L. S., \& Young, A. A., Jr. (2011). Workplace flexibility and worker agency: Finding short-term flexibility within a highly structured workplace. Annals of the American Academy of Political and Social Science, 638, 86-102. doi:10.1177/0002716211415787

*Sav, A., Harris, N., \& Sebar, B. (2014). Australian Muslim men balancing work, family and religion: A positive look at a negative issue. Personnel Review, 43, 2-18.

*Sayah, S. (2013). Managing work-life boundaries with information and communication technologies: The case of independent contractors. New Technology, Work and Employment, 28, 179-196.

*Schilling, E. (2015). 'Success is satisfaction with what you have'? biographical work-life balance of older female employees in public administration. Gender Work and Organization, 22(5), 474-494. doi:10.1111/gwao.12097

*Secret, M., \& Swanberg, J. (2008). Work-family experiences and the insights of municipal government employees: A case study. Public Personnel Management, 37, 199-221.

*Singley, S., \& Hynes, K. (2005). Transitions to parenthood - work-family policies, gender, and the couple context. Gender \& Society, 19(3), 376-397.

doi:10.1177/0891243204271515

*Skinner, N., Elton, J., Auer, J., \& Pocock, B. (2014). Understanding and managing work-life interaction across the life course: A qualitative study. Asia Pacific Journal of Human Resources, 52, 93-109.

*Skinner, N., van Dijk, P., Elton, J., \& Auer, J. (2011). An in-depth study of Australian nurses' and midwives' work-life interaction. Asia Pacific Journal of Human Resources, 49, 213-232.

*Solomon, C. R. (2011). "Sacrificing at the altar of tenure": Assistant professors' work/life management. Social Science Journal, 48(2), 335-344. doi:10.1016/j.soscij.2010.11.006 
*Stalp, M. C., \& Conti, R. (2011). Serious leisure in the home: Professional quilters negotiate family space. Gender, Work and Organization, 18, 399-414.

*Stanko, T. L., \& Beckman, C. M. (2015). Watching you watching me: Boundary control and capturing attention in the context of ubiquitous technology use. Academy of Management Journal, 58(3), 712-738. doi:10.5465/amj.2012.0911

*Sturges, J. (2012). Crafting a balance between work and home. Human Relations, 65, 15391559.

*Suess, S., \& Sayah, S. (2013). Balance between work and life: A qualitative study of German contract workers. European Management Journal, 31, 250-262.

*Thinnam, T. (2011). Married Thai working mothers: Coping with initial part-time doctoral study. Human Resource Development Quarterly, 22, 297-322.

*Tracy, S. J., \& Rivera, K. D. (2010). Endorsing equity and applauding stay-at-home moms: How male voices on work-life reveal aversive sexism and flickers of transformation. Management Communication Quarterly, 24, 3-43.

*Trefalt, S. (2013). Between you and me: Setting work-nonwork boundaries in the context of workplace relationships. Academy of Management Journal, 56, 1802-1829.

"Tsaur, S. H., \& Lin, W. R. (2014). Hassles of tour leaders. Tourism Management, 45, 28-38.

"Turbine, V., \& Riach, K. (2012). The right to choose or choosing what's right? Women's conceptualizations of work and life choices in contemporary Russia. Gender, Work and Organization, 19, 165-187.

"Turner, P. K., \& Norwood, K. (2013). 'I had the luxury...': Organizational breastfeeding support as privatized privilege. Human Relations, 67, 849-874.

*Uttal, L. (1996). Custodial care, surrogate care, and coordinated care - employed mothers and the meaning of child care. Gender \& Society, 10(3), 291-311. doi:10.1177/089124396010003006 
*Vazquez-Carrasco, R., Eugenia Lopez-Perez, M., \& Centeno, E. (2012). A qualitative approach to the challenges for women in management: Are they really starting in the 21st century? Quality \& Quantity, 46(5), 1337-1357. doi:10.1007/s11135-011-9449-6

*von Borell de Araujo, Bruno Felix, Tureta, C. A., \& von Borell de Araujo, Diana Abreu. (2015). How do working mothers negotiate the work-home interface? Journal of Managerial Psychology, 30(5), 565-581. doi:10.1108/JMP-11-2013-0375

“Watts, J. H. (2009). ‘Allowed into a man's world' meanings of work-life balance: Perspectives of women civil engineers as 'minority' workers in construction. Gender, Work and Organization, 6, 37-57.

*Weigt, J. M., \& Solomon, C. R. (2008). Work-family management among low-wage service workers and assistant professors in the USA: A comparative intersectional analysis. Gender, Work and Organization, 15, 621-649.

*Weststar, J. (2012). Negotiating in silence: Experiences with parental leave in academia. Relations Industrielles/Industrial Relations, 67, 352-374.

*Wetlesen, T. S. (2013). Work values in the second generation of gender equality pioneers: A case study from Norway. Gender, Work and Organization, 20, 100-112.

*Wharton, C. (1994). Finding time for the 2nd shift - the impact of flexible work schedules on womens double days. Gender \& Society, 8(2), 189-205.

doi:10.1177/089124394008002004

*Wiersma, U. J. (1994). A taxonomy of behavioral strategies for coping with work-home role conflict. Human Relations, 47, 211-221.

*Windebank, J. (2001). Dual-earner couples in Britain and France: Gender divisions of domestic labour and parenting work in different welfare states. Work, Employment and Society, 15, 269-290. 
Acker, J. (1992). From sex roles to gendered institutions. Contemporary Sociology, 21, 565569.

Allen, T. (2012). The work-family role interface: a synthesis of the research from industrial and organizational psychology. In I. B. Weiner (Eds.), The Oxford handbook of psychology, industrial and organizational psychology (pp.698-718). John Wiley \& Sons.

Allen, T. D., Golden, T. D., \& Shockley, K. M. (2015). How Effective Is Telecommuting? Assessing the Status of Our Scientific Findings. Psychological Science in the Public Interest, 16(2), 40-68.

Allen, T. D., Golden, T. D., \& Shockley, K. M. (2015). How effective is telecommuting? Assessing the status of our scientific findings. Psychological Science in the Public Interest, 16(2), 40-68.

Allen, T. D., Johnson, R. C., Kiburz, K. M., \& Shockley, K. M. (2013). Work-family conflict and flexible work arrangements: Deconstructing flexibility. Personnel Psychology, 66(2), 345-376.

Allen, T. D., Johnson, R.C., Saboe, K.N., Cho, E., Dumani, S., \& Evans, S. (2012). Dispositional variables and work-family conflict: A meta-analysis. Journal of Vocational Behavior, 80, 17-26.

Amstad, F. T., Meier, L. L., Fasel, U., Elfering, A., \& Semmer, N. K. (2011). A metaanalysis of work-family conflict and various outcomes with a special emphasis on cross-domain versus matching-domain relations. Journal of occupational health psychology, 16(2), 151.

Ashforth, B. E., Kreiner, G. E., \& Fugate, M. (2000). All in a day's work: Boundaries and micro role transitions. Academy of Management review, 25(3), 472-491.

Bailyn, L. (1993). Breaking the mold: Women, men, and time in the new corporate world. Ithaca, NY: Cornell University Press. 
Becker, G. (1964). Human capital: A theoretical and empirical analysis, with special reference to education. New York: Columbia University Press.

Bordieu, P. (1987). What makes a social class? On the theoretical and practical existence of groups, Berkeley Journal of Sociology, 32, 1-17.

Bordieu, P. (1990). The logic of practice. Cambridge: Polity Press.

Byron, K. (2005). A meta-analytic review of work-family conflict and its antecedents. Journal of vocational behavior, 67(2), 169-198.

Casper, W. J., Eby, L. T., Bordeaux, C., Lockwood, A., \& Lambert, D. (2007). A review of research methods in IO/OB work-family research. Journal of Applied Psychology, 92, $28-43$.

Clark, S. C. (2000). Work/family border theory: A new theory of work/family balance. Human Relations, 53, 747-770.

Crouter, A. C. (1984). Spillover from family to work: The neglected side of the work-family interface. Human Relations, 37, 425-441.

Dean, M. (1999). Governmentality: Power and rule in modern society. London: SAGE.

Denzin, N. K., \& Lincoln, Y. S. (2000). The SAGE handbook of qualitative research. Thousand Oaks, CA: Sage.

DiMaggio, Paul J. \& Walter W. Powell. (1983). The iron cage revisited: Institutional isomorphism and collective rationality in organizational field. American Sociological Review, 48(2), 147-160.

Eby, L. T., Casper, W. J., Lockwood, A., Bordeaux, C., \& Brinley, A. (2005). Work and family research in IO/OB: Content analysis and review of the literature (1980-2002). Journal of Vocational Behavior, 66, 124-197. 
Edwards, J. R., \& Rothbard, N. P. (2000). Mechanisms linking work and family: Clarifying the relationship between work and family constructs. Academy of Management Review, 25(1), 178-199.

Eisenhardt, K. (1989). Building theories from case study research. The Academy of Management Review, 14, 532-550.

Eräranta, K., \& Moisander, J. (2011). Psychological regimes of truth and father identity: Challenges for work/life integration. Organization Studies, 32, 509-526.

Firmin, M. W., \& Bailey, M. (2008). When caretaking competes with care giving: A qualitative study of full-time working mothers who are nurse managers. Journal of Nursing Management, 16, 858-867.

Ford, M. T., Heinen, B. A., \& Langkamer, K. L. (2007). Work and family satisfaction and conflict: a meta-analysis of cross-domain relations. Journal of Applied Psychology, 92(1), 57.

Foucault, M. (1985). The use of pleasure: The history of sexuality, Vol. 2, trans. Hurley, R. London: Penguin Books.

Franzway, S. (2001). Sexual politics and greedy institutions: Union women, commitments and conflicts in public and private. Sydney: Pluto.

Frone, M. R., Yardley, J. K., \& Markel, K. S. (1997). Developing and testing an integrative model of the work-family interface. Journal of Vocational Behavior, 50, 145-167.

Gatrell, C. J., Burnett, S. B., Cooper, C. L., \& Sparrow, P. (2013). Work-life balance and parenthood: A comparative review of definitions, equity and enrichment. International Journal of Management Reviews, 15, 300-316.

Gephart, R. P. (2004). Qualitative research and the Academy of Management Journal. Academy of Management Journal, 47, 454-462. 
Giddens, A. (1984). The constitution of society: Outline of the theory of structuration. Cambridge, MA: Polity Press.

Greenhaus, J. H., \& Beutell, N. J. (1985). Sources of conflict between work and family roles. Academy of Management Review, 10, 76-88.

Greenhaus, J. H., \& Parasuraman, S. (1999). Research on work, family, and gender: Current status and future directions. In J. H. Greenhaus, S. Parasuraman, \& G. N. Powell (Eds.), Handbook of gender and work (pp. 391-412). Thousand Oaks, CA: Sage.

Greenhaus, J. H., \& Powell, G. N. (2006). When work and family are allies: A theory of work-family enrichment. Academy of Management Review, 31, 72-92.

Greenhaus, J. H., Collins, K. M., \& Shaw, J. D. (2003). The relation between work-family balance and quality of life. Journal of Vocational Behavior, 63, 510-531.

Gregory, A., \& Milner, S. (2009). Trade unions and work-life balance: Changing times in France and the UK. British Journal of Industrial Relations, 47, 122-146.

Grzywacz, J. G., \& Marks, N. F. (2000). Reconceptualizing the work-family interface: An ecological perspective on the correlates of positive and negative spillover between work and family. Journal of Occupational Health Psychology, 5, 111-126.

Hobfoll, S. E. (1989). Conservation of resources: A new attempt at conceptualizing stress. American Psychologist, 44, 513-524.

Jensen, L. A., \& Allen, M. N. (1996). Meta-synthesis of qualitative findings. Qualitative Health Research, 6, 553-560.

Kahn, R. L., Wolfe, D. M., Quinn, R., Snoek, J. D., \& Rosenthal, R. A. (1964). Organizational stress: Studies in role conflict and ambiguity. New York: Wiley.

Kanter, R. M. (1977). Work and family in the United States: A critical review and agenda for research and policy. New York: Russell Sage Foundation. 
Kelly, E. L., Kossek, E. E., Hammer, L. B., Durham, M., Bray, J., Chermack, K., ... \& Kaskubar, D. (2008). Getting There from Here: Research on the Effects of WorkFamily Initiatives on Work-Family Conflict and Business Outcomes. The Academy of Management Annals, 2(1), 305-349.

Kossek, E. E., \& Ozeki, C. (1998). Work-family conflict, policies, and the job-life satisfaction relationship: A review and directions for organizational behavior - human resources research. Journal of Applied Psychology, 83, 139-149.

Kossek, E. E., \& Ozeki, C. (1999). Bridging the work-family policy and productivity gap: A literature review. Community, Work and Family, 2, 7-32.

Kossek, E. E., Pichler, S., Bodner, T., \& Hammer, L. B. (2011). Workplace social support and work-family conflict: A meta-analysis clarifying the influence of general and work-family specific supervisor and organizational support. Personnel Psychology, 64, 289-313.

Layder, D. (1997). Modern social theory: Key debates and new directions. London: University College of London Press.

Lee, T. W., Mitchell, T. R., \& Sablynski, C. J. (1999). Qualitative research in organizational and vocational psychology, 1979-1999. Journal of Vocational Behavior, 55, 161-187.

Lincoln, Y. S., \& Guba, E. G. (1985). Naturalistic inquiry. Newbury Park, CA: Sage.

Maher, J., J. Lindsay \& E.A. Bardoel. (2008). The family time economy: Toward an understanding of time, caring labour, and social policy, Work, Employment and Society, 22(3), 544-52.

Mainiero, L. A., \& Sullivan, S. E. (2005). Kaleidoscope careers: An alternate explanation for the 'opt-out' revolution. Academy of Management Executive, 19, 106-123.

Major, V. S., Klein, K. J., \& Ehrhart, M. G. (2002). Work time, work interference with family, and psychological distress. Journal of Applied Psychology, 87, 427-436. 
Marks, S. R. (1977). Multiple roles and role strain: Some notes on human energy, time and commitment. American Sociological Review, 42(6), 921-936.

McNall, L. A., Nicklin, J. M., \& Masuda, A. D. (2010). A meta-analytic review of the consequences associated with work-family enrichment. Journal of Business and Psychology, 25(3), 381-396.

Merriam, S. (2009). Qualitative research: A guide to design and implementation. San Francisco, CA: Jossey-Bass.

Mesmer-Magnus, J. R., \& Viswesvaran, C. (2005). Convergence between measures of workto-family and family-to-work conflict: A meta-analytic examination. Journal of Vocational Behavior, 67(2), 215-232.

Mesmer-Magnus, J. R., \& Viswesvaran, C. (2006). How family-friendly work environments affect work/family conflict: A meta-analytic examination. Journal of Labor Research, 27, 555-574.

Meyer, J., \& Rowan, B. (1977). Institutionalized organizations: Formal structures as myth and ceremony. American Journal of Sociology, 83(2), 340-363.

Michel, J. S., Kotrba, L. K., Mitchelson, J. K., Clark, M. A., \& Baltes, B. B. (2011). Antecedents of work-family conflict: A meta-analytic review. Journal of Organizational Behavior, 32, 689-725.

Michel, J. S., Mitchelson, J. K., Kotrba, L. M., LeBreton, J. M., \& Baltes, B. B. (2009). A comparative test of work-family conflict models and critical examination of workfamily linkages. Journal of Vocational Behavior, 74(2), 199-218.

Miles, M. B., \& Huberman, A. M. (1994). Qualitative data analysis. CA: Sage.

Mirchandani, K. (1998). Shifting definitions of the public-private dichotomy: Legislative inertia on garment homework in Ontario. Advances in Gender Research, 3, 47-71. Moustakas, C. (1994). Phenomenological research methods. Thousand Oaks, CA: Sage. 
Navarro, P. (2008). The MBA core curricula of top-ranked US business schools: A study in failure? Academy of Management Learning and Education, 7, 108-123.

Neuendorf, K. A. (2002). The content analysis guidebook. London: Sage.

Nippert-Eng, C. E. (1996). Home and work: Negotiating boundaries through everyday life. Chicago, IL: University of Chicago Press.

Özbilgin, M. F., Beauregard, T. A., Tatli, A., \& Bell, M. P. (2011). Work-life, diversity and intersectionality: A critical review and research agenda. International Journal of Management Reviews, 13, 177-198.

Parasuraman, S., \& Greenhaus, J. H. (2002). Toward reducing some critical gaps in work family research. Human Resource Management Review, 12, 299-312.

Rothman, B. (1994). Beyond mothers and fathers: Ideology in a patriarchal society. In E.N. Glenn, G. Chang \& L.R. Forcie (Eds.), Mothering: Ideology, Experience and Agency (139-57). New York: Routledge.

Shockley, K. M., \& Singla, N. (2011). Reconsidering work-family interactions and satisfaction: A meta-analysis. Journal of Management, 37(3), 861-886.

Sieber, S. D. (1974). Toward a theory of role accumulation. American sociological review, 39: 567578.

Silva, S., \& Ramos, S. (2013). Research methods in management academic programs: From where we are to where we want to go. In I. Ramos, \& A. Mesquita (Eds.), Proceedings of the 12th European conference on research methods (pp. 333-337).

UK: Academic Conferences and Publishing.

Smith, D. (1987). The everyday world as problematic: A feminist sociology. Boston, MA: Northeastern University Press.

Stake, R. E. (1995). The art of case study research. Thousand Oaks, CA: Sage.

Taylor, F. W. (1911). Principles of scientific management. New York, NY: Harper Brothers. 
West, C., \& Zimmerman, D. H. (2002). Doing gender. In S. Fenstermaker \& C. West (Eds.), Doing gender, doing difference, New York: Routledge.

Williams, J. (2000). Unbending gender: Why family and work conflict and what to do about it. Oxford, UK: Oxford University Press.

Williams, J. (2000). Unbending gender: Why work and family conflict and what to do about it. New York: Oxford University Press.

Wright, P. M., Dunford, B. B., \& Snell S. A. (2001). Human resources and the resource based view of the firm. Journal of Management, 27, 701-721.

Zedeck, S. (1992). Work, families, and organizations. San Francisco, CA: Jossey-Bass.

Zimmerman, T. S., Haddock, S. A., Current, L. R., \& Ziemba, S. (2003). Intimate partnership: Foundation to the successful balance of family and work. The American Journal of Family Therapy, 31, 107-124. 
Appendix

Table 1

Frequency of articles by journals

\begin{tabular}{|c|c|}
\hline Journal Title & Frequency $^{*}$ \\
\hline Gender Work and Organization & 17 \\
\hline Human Relations & 9 \\
\hline $\begin{array}{l}\text { Academy of Management Journal; International Journal of Human Resource } \\
\text { Management; Personnel Review }\end{array}$ & 5 \\
\hline $\begin{array}{l}\text { Gender \& Society; Journal of Management \& Organization; Journal of } \\
\text { Managerial Psychology; New Technology Work and Employment; Work } \\
\text { Employment and Society }\end{array}$ & 4 \\
\hline $\begin{array}{l}\text { British Journal of Management; European Management Journal; Human } \\
\text { Resource management; Journal of Employment Counseling; Journal of } \\
\text { Occupational and Organizational Psychology; Journal of Social Policy; } \\
\text { Journal of Vocational Behavior; Sociological Research Online; } \\
\text { Sociological Review; Work and Occupations }\end{array}$ & 3 \\
\hline $\begin{array}{l}\text { Asia Pacific Journal of Human Resources; Canadian Journal of Sociology- } \\
\text { Cahiers Canadiens De Sociologie ; Canadian Review of Sociology and } \\
\text { Anthropology-Revue Canadienne De Sociologie Et D Anthropologie; } \\
\text { Journal of Business and Psychology; Journal of Counseling and } \\
\text { Development; Journal of Marriage and Family; Journal of Sport } \\
\text { Management; Management Communication Quarterly; Relations } \\
\text { Industrielles-Industrial Relations; Sociology-the Journal of the British } \\
\text { Sociological Association; Journal of Industrial Relations }\end{array}$ & 2 \\
\hline $\begin{array}{l}\text { Academia-Revista Latinoamericana De Administracion; Acta Sociologica; } \\
\text { Administrative Science Quarterly; Annals of the American Academy of } \\
\text { Political and Social Science; Australian Journal of Management; Career } \\
\text { Development International; Childhood-a Global Journal of Child } \\
\text { Research; Creativity and Innovation Management; Culture and } \\
\text { Organization; Current Sociology; Disability \& Society; Economic and } \\
\text { Industrial Democracy; Employee Relations; Entrepreneurship and } \\
\text { Regional Development; European Journal of Industrial Relations; Group } \\
\text { \& Organization Management; Human Resource Development Quarterly; } \\
\text { Information and Organization; International Journal of Contemporary } \\
\text { Hospitality Management; International Small Business Journal; Journal } \\
\text { of Career Development; Journal of Management Inquiry; Journal of } \\
\text { nursing management; Journal of Organizational Behavior; Journal of } \\
\text { Sociology; Leisure Sciences; Organization Studies; Public Personnel } \\
\text { Management; Quality \& Quantity; Scandinavian Journal of Hospitality } \\
\text { and Tourism; Social Policy \& Administration; Social Science Journal; } \\
\text { Sociological Forum; Sociological Spectrum; Sociology of Health \& } \\
\text { Illness; South African Journal of Economic and Management Sciences; } \\
\text { Tourism Management; Zeitschrift Fur Personalforschung; Time and } \\
\text { Society }\end{array}$ & 1 \\
\hline
\end{tabular}


Table 2

Reviewed Articles: Authors, Journals, Country, Research Approach, and Major Focus

\begin{tabular}{|c|c|c|c|c|}
\hline Author(s) (Year) & $\begin{array}{l}\text { Periodical } \\
\text { Abbrev }\end{array}$ & Country & Research Approach & Focus \\
\hline $\begin{array}{l}\text { Abbott and De Cieri } \\
(2008)\end{array}$ & J.Manag.Organ. & Australia & Case studies & $\begin{array}{l}\text { Management and employee } \\
\text { perspectives of WLB }\end{array}$ \\
\hline $\begin{array}{l}\text { Abstein and Spieth } \\
\text { (2014) }\end{array}$ & $\begin{array}{l}\text { Creat. Innov. } \\
\text { Manag. }\end{array}$ & Germany & Qualitative & $\begin{array}{l}\text { Work-family policy and } \\
\text { HRM }\end{array}$ \\
\hline Ammons (2013) & J.Vocat.Behav. & The US & Qualitative & $\begin{array}{l}\text { Preferred and enacted work- } \\
\text { family boundaries }\end{array}$ \\
\hline Armstrong (2006) & $\begin{array}{l}\text { Sociol. Res. } \\
\text { Online }\end{array}$ & The UK & Interview Study & $\begin{array}{l}\text { Motherhood and } \\
\text { employment }\end{array}$ \\
\hline $\mathrm{Ba}^{\prime}(2010)$ & $\begin{array}{l}\text { Sociol. Res. } \\
\text { Online }\end{array}$ & The UK & Qualitative & $\begin{array}{l}\text { The WFI among working } \\
\text { couples }\end{array}$ \\
\hline $\begin{array}{l}\text { Backett-Milburn et } \\
\text { al. (2008) }\end{array}$ & Sociol. Rev. & The UK & Qualitative & $\begin{array}{l}\text { WLB issues amongst female } \\
\text { employees }\end{array}$ \\
\hline $\begin{array}{l}\text { Bakker and Karsten } \\
\text { (2013) }\end{array}$ & Acta Sociol. & Netherlands & Qualitative & $\begin{array}{l}\text { Single parent and co-parents } \\
\text { role balance }\end{array}$ \\
\hline $\begin{array}{l}\text { Baldock and } \\
\text { Hadlow (2004) }\end{array}$ & Soc.Policy Adm. & $\begin{array}{l}\text { Finland, } \\
\text { France, } \\
\text { Italy, } \\
\text { Portugal and } \\
\text { the UK }\end{array}$ & $\begin{array}{l}\text { Qualitative responses } \\
\text { to open-ended } \\
\text { questions in a } \\
\text { questionnaire }\end{array}$ & $\begin{array}{l}\text { Work-family experiences of } \\
\text { parents }\end{array}$ \\
\hline Bardoel et al. (2008) & J.Manag.Organ. & Australia & Qualitative & $\begin{array}{l}\text { Practitioner and research } \\
\text { understandings of work-life } \\
\text { measurement }\end{array}$ \\
\hline $\begin{array}{l}\text { Becker and Moen } \\
\text { (1999) }\end{array}$ & J. Marriage Fam. & The US & Interview Study & $\begin{array}{l}\text { Couples' work-family } \\
\text { strategies }\end{array}$ \\
\hline Berg et al. (2013) & Eur.Manag.J. & $\begin{array}{l}\text { Australia } \\
\text { and the US }\end{array}$ & $\begin{array}{l}\text { Qualitative } \\
\text { methodology }\end{array}$ & $\begin{array}{l}\text { Work-family policy and } \\
\text { collective bargaining }\end{array}$ \\
\hline Bjornholt (2014) & Sociol. Rev. & Norway & Qualitative & $\begin{array}{l}\text { The work-family adaptations } \\
\text { of men in two generations }\end{array}$ \\
\hline Blain (1993) & $\begin{array}{l}\text { Can. J. Sociol.- } \\
\text { Cahiers Can. } \\
\text { Sociol. }\end{array}$ & The UAE & Qualitative & $\begin{array}{l}\text { Dealing with conflicts } \\
\text { between sickness of a child } \\
\text { and the paid work }\end{array}$ \\
\hline Blair-Loy (2009) & Work Occup. & The US & Case study & $\begin{array}{l}\text { Work-family experiences of } \\
\text { Stockbrokers }\end{array}$ \\
\hline Blumen (2015) & $\begin{array}{l}\text { J. Manage. } \\
\text { Psychol. }\end{array}$ & Israel & $\begin{array}{l}\text { Phenomenological } \\
\text { Study }\end{array}$ & The WFI of R\&D engineers \\
\hline $\begin{array}{l}\text { Borve and Bungum } \\
\text { (2015) }\end{array}$ & $\begin{array}{l}\text { Gend. Work. } \\
\text { Organ. }\end{array}$ & Norway & Qualitative & $\begin{array}{l}\text { Work-family conditions } \\
\text { when the fathers are working } \\
\text { in global companies }\end{array}$ \\
\hline $\begin{array}{l}\text { Bourne and Forman } \\
\text { (2014) }\end{array}$ & J.Manage.Inq. & The US & Ethnographic study & $\begin{array}{l}\text { Work-family and work } \\
\text { flexibility }\end{array}$ \\
\hline $\begin{array}{l}\text { Burchielli et al. } \\
\text { (2008) }\end{array}$ & $\begin{array}{l}\text { Relat. Ind.-Ind. } \\
\text { Relat. }\end{array}$ & Australia & Qualitative & $\begin{array}{l}\text { Work-family balance of } \\
\text { senior staff and managers }\end{array}$ \\
\hline Burnett et al. (2013) & $\begin{array}{l}\text { Gend.Work.Orga } \\
\mathrm{n} \text {. }\end{array}$ & The UK & $\begin{array}{l}\text { Empirical study using } \\
\text { qualitative data }\end{array}$ & $\begin{array}{l}\text { Work-family policy and } \\
\text { fathering }\end{array}$ \\
\hline $\begin{array}{l}\text { Cahusac and Kanji } \\
\text { (2014) }\end{array}$ & $\begin{array}{l}\text { Gend.Work.Orga } \\
\text { n. }\end{array}$ & The UK & $\begin{array}{l}\text { Qualitative } \\
\text { interviews }\end{array}$ & $\begin{array}{l}\text { Work-family experiences of } \\
\text { mothers }\end{array}$ \\
\hline $\begin{array}{l}\text { Carrigan and } \\
\text { Duberley (2013) }\end{array}$ & Time Soc. & The UK & Qualitative & $\begin{array}{l}\text { Women entrepreneurs with } \\
\text { children }\end{array}$ \\
\hline Chandra (2012) & $\begin{array}{l}\text { Int. J. Hum. } \\
\text { Resour. Manag. }\end{array}$ & $\begin{array}{l}\text { India and } \\
\text { multinationa } \\
1 \text { companies }\end{array}$ & Qualitative & $\begin{array}{l}\text { Western and Eastern } \\
\text { approaches to WLB }\end{array}$ \\
\hline Christopher (2012) & Gend. Soc. & The US & Qualitative & $\begin{array}{l}\text { Motherhood and } \\
\text { employment }\end{array}$ \\
\hline
\end{tabular}




\begin{tabular}{|c|c|c|c|c|}
\hline Author(s) (Year) & $\begin{array}{l}\text { Periodical } \\
\text { Abbrev }\end{array}$ & Country & Research Approach & Focus \\
\hline Clarke (2015) & Career Dev. Int. & Australia & Interview study & $\begin{array}{l}\text { Career decisions of } \\
\text { professional couples with an } \\
\text { attempt to balance work and } \\
\text { family }\end{array}$ \\
\hline $\begin{array}{l}\text { Cook and Shinew } \\
\text { (2014) }\end{array}$ & Leis. Sci. & The US & Interview study & $\begin{array}{l}\text { The significance of leisure in } \\
\text { their work and personal lives }\end{array}$ \\
\hline $\begin{array}{l}\text { Cooke and Xiao } \\
(2014)\end{array}$ & $\begin{array}{l}\text { Hum.Resour.Ma } \\
\text { nage. }\end{array}$ & China & Qualitative method & $\begin{array}{l}\text { Work-family experiences of } \\
\text { women in Accountancy and } \\
\text { Consultancy Firms }\end{array}$ \\
\hline $\begin{array}{l}\text { Crompton and } \\
\text { Lyonette (2011) }\end{array}$ & $\begin{array}{l}\text { Gend.Work.Orga } \\
\text { n. }\end{array}$ & The UK & Interview study & $\begin{array}{l}\text { Family-friendly employment } \\
\text { options and gendered career } \\
\text { paths }\end{array}$ \\
\hline $\begin{array}{l}\text { Cunningham-Burley } \\
\text { et al. (2006) }\end{array}$ & $\begin{array}{l}\text { Sociol. Health } \\
\text { Ill. }\end{array}$ & The UK & Qualitative & $\begin{array}{l}\text { Working mothers interface } \\
\text { between work, family, health } \\
\text { and sickness }\end{array}$ \\
\hline D'Abate (2005) & Hum. Relat. & - & Qualitative & Work-family experiences \\
\hline $\begin{array}{l}\text { Damaske et al. } \\
\text { (2014) }\end{array}$ & Work Occup. & The US & Qualitative & $\begin{array}{l}\text { Work-family experiences of } \\
\text { academic scientists }\end{array}$ \\
\hline Dean (2007) & J.Soc.Policy & The UK & Qualitative & $\begin{array}{l}\text { Work-family experiences in } \\
\text { a low-income } \\
\text { neighbourhood }\end{array}$ \\
\hline $\begin{array}{l}\text { Delong and Delong } \\
\text { (1992) }\end{array}$ & $\begin{array}{l}\text { Hum.Resour.Ma } \\
\text { nage. }\end{array}$ & - & Qualitative & $\begin{array}{l}\text { Work-family style of father } \\
\text { managers }\end{array}$ \\
\hline $\begin{array}{l}\text { Di Domenico et al. } \\
\text { (2014) }\end{array}$ & $\begin{array}{l}\text { New } \\
\text { Technol.Work } \\
\text { Employ. }\end{array}$ & The UK & $\begin{array}{l}\text { Qualitative inductive } \\
\text { methods }\end{array}$ & $\begin{array}{l}\text { Work-family and online } \\
\text { home-based business }\end{array}$ \\
\hline $\begin{array}{l}\text { Emslie and Hunt } \\
\text { (2009) }\end{array}$ & $\begin{array}{l}\text { Gend.Work.Orga } \\
\text { n. }\end{array}$ & The UK & Qualitative & $\begin{array}{l}\text { Work-family experiences of } \\
\text { mid-life individuals }\end{array}$ \\
\hline $\begin{array}{l}\text { Eräranta and } \\
\text { Moisander (2011) }\end{array}$ & Organ.Stud. & Finland & Case study & $\begin{array}{l}\text { Work-family challenges of } \\
\text { fathers in Psychological } \\
\text { Regimes of Truth }\end{array}$ \\
\hline Fincham (2008) & $\begin{array}{l}\text { Sociol.-J. Brit. } \\
\text { Sociol. Assoc. }\end{array}$ & The UK & Ethnography & Bicycle messengers' WFI \\
\hline $\begin{array}{l}\text { Firmin and Bailey } \\
(2008)\end{array}$ & J.Nurs.Manag. & The US & $\begin{array}{l}\text { Phenomenological } \\
\text { study }\end{array}$ & $\begin{array}{l}\text { Work-family experiences of } \\
\text { mothers }\end{array}$ \\
\hline $\begin{array}{l}\text { Fischlmayr and } \\
\text { Kollinger (2010) }\end{array}$ & $\begin{array}{l}\text { Int. J. Hum. } \\
\text { Resour. Manag. }\end{array}$ & Austria & Qualitative & $\begin{array}{l}\text { Work-family experiences of } \\
\text { female expatriates }\end{array}$ \\
\hline $\begin{array}{l}\text { Fonner and Stache } \\
\text { (2012) }\end{array}$ & $\begin{array}{l}\text { New Technol. } \\
\text { Work Employ. }\end{array}$ & - & Qualitative & $\begin{array}{l}\text { Work-family boundary } \\
\text { management among home- } \\
\text { based teleworkers }\end{array}$ \\
\hline $\begin{array}{l}\text { Frame and Shehan } \\
(2005)\end{array}$ & J.Employ.Couns. & The US & Qualitative & $\begin{array}{l}\text { Work-family experiences of } \\
\text { women in a male-dominated } \\
\text { profession }\end{array}$ \\
\hline $\begin{array}{l}\text { Fujimoto et al. } \\
\text { (2013) }\end{array}$ & Aust. J. Manag. & Australia & Qualitative & Work-family and gender \\
\hline Furbish (2009) & J.Employ.Couns. & $\begin{array}{l}\text { New } \\
\text { Zealand }\end{array}$ & Interview study & Self-funded leave programs \\
\hline Galea et al. (2014) & $\begin{array}{l}\text { Int. J. Hum. } \\
\text { Resour. Manag. }\end{array}$ & $\begin{array}{l}\text { Luxembourg } \\
\text { and the } \\
\text { Netherlands }\end{array}$ & Qualitative & $\begin{array}{l}\text { Work-family and flexible } \\
\text { work }\end{array}$ \\
\hline Gatrell et al. (2014) & Br.J.Manage. & The UK & Qualitative & $\begin{array}{l}\text { Flexible work and parents' } \\
\text { work-family }\end{array}$ \\
\hline George et al. (2008) & J. Manag. Organ. & Australia & Qualitative & $\begin{array}{l}\text { Work-family experiences of } \\
\text { parents with children with } \\
\text { chronic illness }\end{array}$ \\
\hline Gherardi (2015) & Int. Small Bus. J. & Italy & Narrative approach & $\begin{array}{l}\text { Gender and entrepreneurship } \\
\text { and authoring of identity }\end{array}$ \\
\hline
\end{tabular}




\begin{tabular}{|c|c|c|c|c|}
\hline Author(s) (Year) & $\begin{array}{l}\text { Periodical } \\
\text { Abbrev }\end{array}$ & Country & Research Approach & Focus \\
\hline Golden (2009) & $\begin{array}{l}\text { Manage.Commu } \\
\text { n.Q. }\end{array}$ & The US & Interview study & $\begin{array}{l}\text { Sense making in work- } \\
\text { family interrelationships }\end{array}$ \\
\hline $\begin{array}{l}\text { Golden and Geisler } \\
\text { (2007) }\end{array}$ & Hum.Relat. & The US & Qualitative & $\begin{array}{l}\text { Using PDA as a work-life } \\
\text { boundary management } \\
\text { resource }\end{array}$ \\
\hline Gordon et al. (2015) & $\begin{array}{l}\text { Can. Rev. } \\
\text { Sociol. }\end{array}$ & Canada & Multiple case study & Flexible workplace policies \\
\hline $\begin{array}{l}\text { Grady and } \\
\text { McCarthy (2008) }\end{array}$ & $\begin{array}{l}\text { Anthropol.-Rev. } \\
\text { J.Manage.Psycho } \\
\text { l. }\end{array}$ & Ireland & Qualitative & $\begin{array}{l}\text { Work-family experiences of } \\
\text { professional working } \\
\text { mothers }\end{array}$ \\
\hline $\begin{array}{l}\text { Grant, Wallace, and } \\
\text { Spurgeon (2013) }\end{array}$ & Empl.Relat. & The UK & Qualitative & $\begin{array}{l}\text { Work-family experiences of } \\
\text { remote workers and e- } \\
\text { workers }\end{array}$ \\
\hline $\begin{array}{l}\text { Grant-Vallone and } \\
\text { Ensher (2011) }\end{array}$ & J.Career Dev. & The US & Qualitative & $\begin{array}{l}\text { Work-family experiences of } \\
\text { professional women }\end{array}$ \\
\hline Gray (2006) & $\begin{array}{l}\text { Sociol. Res. } \\
\text { Online }\end{array}$ & The UK & Qualitative & Parenting and childcare \\
\hline $\begin{array}{l}\text { Greer and Peterson } \\
(2013)\end{array}$ & Sociol. Spectr. & The US & $\begin{array}{l}\text { Qualitative- } \\
\text { Document content } \\
\text { analysis }\end{array}$ & $\begin{array}{l}\text { Representations of balance } \\
\text { in work and family life in } \\
\text { media }\end{array}$ \\
\hline Guendouzi (2006) & J. Marriage Fam. & The UK & Qualitative & $\begin{array}{l}\text { women balancing domestic } \\
\text { and professional roles }\end{array}$ \\
\hline $\begin{array}{l}\text { Hantrais and Ackers } \\
(2005)\end{array}$ & Eur.J.Ind.Relat. & $\begin{array}{l}\text { France, } \\
\text { Spain and } \\
\text { Poland }\end{array}$ & Qualitative & $\begin{array}{l}\text { WLB choices of individuals } \\
\text { from France, Spain and } \\
\text { Poland }\end{array}$ \\
\hline Hashiguchi (2010) & $\begin{array}{l}\text { Econ.Ind.Democ } \\
\text { r. }\end{array}$ & The UK & Ethnography & Maternity leave \\
\hline Hestbaek (1998) & $\begin{array}{l}\text { Child.-Glob. J. } \\
\text { Child Res. }\end{array}$ & Denmark & Qualitative & Dual earners' parenting \\
\hline $\begin{array}{l}\text { Hilbrecht et al. } \\
\text { (2008) }\end{array}$ & $\begin{array}{l}\text { New } \\
\text { Technol.Work } \\
\text { Employ. }\end{array}$ & Canada & Qualitative & $\begin{array}{l}\text { Work-family experience of } \\
\text { teleworking mothers }\end{array}$ \\
\hline $\begin{array}{l}\text { Hilbrecht et al. } \\
\text { (2013) }\end{array}$ & $\begin{array}{l}\text { Gend.Work.Orga } \\
\text { n. }\end{array}$ & Canada & Qualitative & $\begin{array}{l}\text { Work-family experiences of } \\
\text { teleworkers }\end{array}$ \\
\hline $\begin{array}{l}\text { Hislop and Axtell } \\
\text { (2011) }\end{array}$ & Inf.Organ. & The UK & Multiple case study & $\begin{array}{l}\text { Work-family boundary } \\
\text { management among mobile } \\
\text { service engineers }\end{array}$ \\
\hline Hughes (2013) & Curr. Sociol. & Australia & Qualitative & $\begin{array}{l}\text { Work-family among young } \\
\text { adults }\end{array}$ \\
\hline $\begin{array}{l}\text { Hughes and } \\
\text { Bozionelos (2007) }\end{array}$ & Pers. Rev. & The UK & Qualitative & $\begin{array}{l}\text { Work-family issues of bus } \\
\text { drivers }\end{array}$ \\
\hline $\begin{array}{l}\text { Humberd et al. } \\
\text { (2015) }\end{array}$ & J. Bus. Psychol. & The US & Interview study & $\begin{array}{l}\text { Work-family experiences of } \\
\text { fathers }\end{array}$ \\
\hline $\begin{array}{l}\text { Humberd et al. } \\
\text { (2015) }\end{array}$ & J. Bus. Psychol. & The US & Interview study & Experiences of fatherhood \\
\hline $\begin{array}{l}\text { Jackson and } \\
\text { Scharman (2002) }\end{array}$ & J.Couns.Dev. & The US & Qualitative & $\begin{array}{l}\text { Work-family experiences of } \\
\text { married mothers }\end{array}$ \\
\hline Jacobs et al. (2008) & $\begin{array}{l}\text { S.Afr.J.Econ.Ma } \\
\text { nag.Sci. }\end{array}$ & South Africa & Qualitative & $\begin{array}{l}\text { Coping strategies among } \\
\text { mining employees }\end{array}$ \\
\hline Kamenou (2008) & Br.J.Manage. & The UK & Qualitative & $\begin{array}{l}\text { Work-family experiences of } \\
\text { ethnic minority women }\end{array}$ \\
\hline $\begin{array}{l}\text { Kim and Faerman } \\
\text { (2013) }\end{array}$ & Eur.Manag.J. & Korea & - & Family-friendly policies \\
\hline $\begin{array}{l}\text { Kirkwood and } \\
\text { Tootell (2008) }\end{array}$ & J.Manag.Organ. & $\begin{array}{l}\text { New } \\
\text { Zealand }\end{array}$ & Qualitative & $\begin{array}{l}\text { Work-family experiences of } \\
\text { women entrepreneurs }\end{array}$ \\
\hline
\end{tabular}




\begin{tabular}{|c|c|c|c|c|}
\hline Author(s) (Year) & $\begin{array}{l}\text { Periodical } \\
\text { Abbrev }\end{array}$ & Country & Research Approach & Focus \\
\hline $\begin{array}{l}\text { Kollinger-Santer } \\
\text { and Fischlmayr } \\
(2013)\end{array}$ & $\begin{array}{l}\text { Z. } \\
\text { Personalforsch. }\end{array}$ & Germany & Qualitative & $\begin{array}{l}\text { Work-family experiences of } \\
\text { business travelers }\end{array}$ \\
\hline Kreiner et al. (2009) & Acad. Manage. J. & The US & Qualitative & $\begin{array}{l}\text { Work-family dimensions, } \\
\text { consequences, and process }\end{array}$ \\
\hline Ladge et al. (2012) & Acad. Manage. J. & The US & Grounded theory & $\begin{array}{l}\text { Work experiences and } \\
\text { identity transition during } \\
\text { pregnancy }\end{array}$ \\
\hline $\begin{array}{l}\text { Leberman and } \\
\text { LaVoi }(2011)\end{array}$ & J.Sport Manage. & The US & $\begin{array}{l}\text { Phenomenological } \\
\text { approach }\end{array}$ & $\begin{array}{l}\text { Work-family experiences of } \\
\text { working mother-coaches }\end{array}$ \\
\hline $\begin{array}{l}\text { Leberman and } \\
\text { Palmer (2009) }\end{array}$ & J.Sport Manage. & $\begin{array}{l}\text { New } \\
\text { Zealand }\end{array}$ & Interview study & $\begin{array}{l}\text { Work-family experiences of } \\
\text { mothers in elite sport } \\
\text { leadership }\end{array}$ \\
\hline Lee et al. (2011) & Hum. Relat. & $\begin{array}{l}\text { The US and } \\
\text { Canada }\end{array}$ & $\begin{array}{l}\text { Ethnography- } \\
\text { longitudinal field } \\
\text { study }\end{array}$ & $\begin{array}{l}\text { Work-family coordination } \\
\text { over time }\end{array}$ \\
\hline $\begin{array}{l}\text { Lewis and Smithson } \\
\text { (2001) }\end{array}$ & Hum.Relat. & $\begin{array}{l}\text { Norway, } \\
\text { Sweden, } \\
\text { Portugal, } \\
\text { Ireland and } \\
\text { The UK }\end{array}$ & Qualitative & $\begin{array}{l}\text { European young adults } \\
\text { expectations for work-family } \\
\text { support }\end{array}$ \\
\hline Lewis et al. (1999) & Disabil. Soc. & The UK & Qualitative & $\begin{array}{l}\text { Employed mothers with } \\
\text { disables children }\end{array}$ \\
\hline Lewis et al. (2000) & Pers.Rev. & - & Qualitative & $\begin{array}{l}\text { Work-family experience of } \\
\text { parents with disabled } \\
\text { children }\end{array}$ \\
\hline $\begin{array}{l}\text { Linehan and Walsh } \\
(2000)\end{array}$ & Br.J.Manage. & $\begin{array}{l}\text { Ireland, } \\
\text { Belgium, } \\
\text { England, } \\
\text { Germany }\end{array}$ & Qualitative & $\begin{array}{l}\text { Work-family experience of } \\
\text { senior international } \\
\text { managers }\end{array}$ \\
\hline $\begin{array}{l}\text { Litrico and Lee } \\
(2008)\end{array}$ & J.Organ.Behav. & - & Multiple case study & $\begin{array}{l}\text { Alternative work } \\
\text { arrangements in professional } \\
\text { services firms }\end{array}$ \\
\hline Lo (2003) & Pers.Rev. & Hong Kong & Qualitative & $\begin{array}{l}\text { Work-family experiences of } \\
\text { married female professionals }\end{array}$ \\
\hline $\begin{array}{l}\text { Loevhoeiden et al. } \\
\text { (2011) }\end{array}$ & $\begin{array}{l}\text { Scand. J. Hosp. } \\
\text { Tour. }\end{array}$ & Norway & Exploratory study & $\begin{array}{l}\text { Work-family conflict and } \\
\text { work-family enrichment } \\
\text { among middle managers }\end{array}$ \\
\hline Loscocco (1997) & J.Vocat.Behav. & The US & Qualitative & $\begin{array}{l}\text { Work-family experiences of } \\
\text { self-employed individuals }\end{array}$ \\
\hline $\begin{array}{l}\text { Lowson and Arber } \\
\text { (2014) }\end{array}$ & $\begin{array}{l}\text { Gend.Work.Orga } \\
\mathrm{n} .\end{array}$ & The UK & Qualitative accounts & Work-family and night work \\
\hline Maher (2013) & $\begin{array}{l}\text { Gend.Work.Orga } \\
\mathrm{n} .\end{array}$ & Australia & Interview study & Employment and family care \\
\hline Maher et al. (2010) & $\begin{array}{l}\text { Sociol.-J. Brit. } \\
\text { Sociol. Assoc. }\end{array}$ & Australia & Interview Study & $\begin{array}{l}\text { Coordination of work and } \\
\text { care responsibilities }\end{array}$ \\
\hline $\begin{array}{l}\text { Matthews et al. } \\
(2011)\end{array}$ & J.Vocat.Behav. & The US & Grounded Theory & $\begin{array}{l}\text { Work-family experiences of } \\
\text { parents of children with } \\
\text { autism }\end{array}$ \\
\hline $\begin{array}{l}\text { McDonald et al. } \\
\text { (2007) }\end{array}$ & $\begin{array}{l}\text { Int.J.Hum.Resou } \\
\text { r.Manag. }\end{array}$ & Australia & Qualitative & $\begin{array}{l}\text { Strategies to ease work-life } \\
\text { policies application }\end{array}$ \\
\hline $\begin{array}{l}\text { McDonald, } \\
\text { Townsend, and } \\
\text { Wharton (2013) }\end{array}$ & Pers.Rev. & Australia & Qualitative & $\begin{array}{l}\text { Work-family discourse in } \\
\text { construction industry }\end{array}$ \\
\hline McGowan (2009) & Cult.Organ. & Canada & Discourse analysis & $\begin{array}{l}\text { Managerial discourses of } \\
\text { work and eldercare }\end{array}$ \\
\hline
\end{tabular}




\begin{tabular}{|c|c|c|c|c|}
\hline Author(s) (Year) & $\begin{array}{l}\text { Periodical } \\
\text { Abbrev }\end{array}$ & Country & Research Approach & Focus \\
\hline $\begin{array}{l}\text { McGowan, Redeker, } \\
\text { Cooper, and } \\
\text { Greenan }(2012)\end{array}$ & Entrep.Reg.Dev. & $\begin{array}{l}\text { Northern } \\
\text { Ireland }\end{array}$ & Qualitative & $\begin{array}{l}\text { Work-family experiences of } \\
\text { women business owners }\end{array}$ \\
\hline McKie et al. (2009) & $\begin{array}{l}\text { Work } \\
\text { Employ.Soc. }\end{array}$ & Scotland & Interview study & $\begin{array}{l}\text { Work-family experiences of } \\
\text { low-paid women working in } \\
\text { food retail }\end{array}$ \\
\hline $\begin{array}{l}\text { Millar and Ridge } \\
(2009)\end{array}$ & J.Soc.Policy & The UK & Qualitative & $\begin{array}{l}\text { Social relationships and } \\
\text { lone mothers employment } \\
\text { sustainability }\end{array}$ \\
\hline Millward (2006) & $\begin{array}{l}\text { J.Occup.Organ.P } \\
\text { sychol. }\end{array}$ & The UK & Phenomenology & $\begin{array}{l}\text { Maternity leave policy for } \\
\text { mothers }\end{array}$ \\
\hline Mirchandani (1999) & $\begin{array}{l}\text { Can. Rev. } \\
\text { Sociol. } \\
\text { Anthropol.-Rev. }\end{array}$ & Canada & Qualitative & $\begin{array}{l}\text { Teleworkers' separation } \\
\text { between public/work and } \\
\text { private/nonwork }\end{array}$ \\
\hline Moen et al. (2013) & Work Occup. & The US & Qualitative & $\begin{array}{l}\text { Work-family strategies } \\
\text { among professionals }\end{array}$ \\
\hline Morehead (2001) & $\begin{array}{l}\text { Journal of } \\
\text { Sociology }\end{array}$ & Australia & Qualitative & $\begin{array}{l}\text { Employed mothers work- } \\
\text { family }\end{array}$ \\
\hline $\begin{array}{l}\text { Motro and } \\
\text { Vanneman (2015) }\end{array}$ & Sociol. Forum & - & Qualitative & Working mothers \\
\hline $\operatorname{Nadim}(2014)$ & Sociol. Rev. & Norway & Qualitative & Motherhood and paid work \\
\hline $\begin{array}{l}\text { Neiterman and Lobb } \\
\text { (2014) }\end{array}$ & $\begin{array}{l}\text { Gend.Work.Orga } \\
\text { n. }\end{array}$ & Canada & - & Work-family and attrition \\
\hline Oliver (2012) & $\begin{array}{l}\text { Int.J.Hum.Resou } \\
\text { r.Manag. }\end{array}$ & $\begin{array}{l}\text { The UK, } \\
\text { Austria, } \\
\text { Greece, Italy } \\
\text { and Portugal }\end{array}$ & Interview study & $\begin{array}{l}\text { Work-family issues of } \\
\text { science researchers }\end{array}$ \\
\hline $\begin{array}{l}\text { Ollier-Malaterre } \\
(2010)\end{array}$ & Hum.Relat. & $\begin{array}{l}\text { The US and } \\
\text { the UK }\end{array}$ & Case study & $\begin{array}{l}\text { Outcomes of the Work- } \\
\text { family initiatives }\end{array}$ \\
\hline O'Neill (2012) & $\begin{array}{l}\text { Int. J. Contemp. } \\
\text { Hosp. Manag. }\end{array}$ & The USA & Qualitative & $\begin{array}{l}\text { Work-family issues among } \\
\text { entrants to the hospitality } \\
\text { management }\end{array}$ \\
\hline $\begin{array}{l}\text { O'Ryan and } \\
\text { McFarland (2010) }\end{array}$ & J.Couns.Dev. & The US & Phenomenology & $\begin{array}{l}\text { Work-family experiences of } \\
\text { lesbian and gay couples }\end{array}$ \\
\hline $\begin{array}{l}\text { Pedersen and Lewis } \\
(2012)\end{array}$ & $\begin{array}{l}\text { Work } \\
\text { Employ.Soc. }\end{array}$ & Denmark & Qualitative & $\begin{array}{l}\text { Flexible working time } \\
\text { arrangements, work-family, } \\
\text { and friendship }\end{array}$ \\
\hline Perlow (1995) & $\begin{array}{l}\text { Group } \\
\text { Organ.Manage. }\end{array}$ & The US & $\begin{array}{l}\text { Ethnography- Field } \\
\text { study }\end{array}$ & WLB policies \& barriers \\
\hline Perlow (1998) & Adm.Sci.Q. & - & Qualitative & $\begin{array}{l}\text { Work-family experiences of } \\
\text { managers in WF boundary } \\
\text { control }\end{array}$ \\
\hline Perrons (2003) & $\begin{array}{l}\text { Gend.Work.Orga } \\
\mathrm{n} .\end{array}$ & The UK & Case study & $\begin{array}{l}\text { Work-family experiences of } \\
\text { media sector employees }\end{array}$ \\
\hline $\begin{array}{l}\text { Peus and Traut- } \\
\text { Mattausch (2008) }\end{array}$ & $\begin{array}{l}\text { J.Manage.Psycho } \\
\text { l. }\end{array}$ & $\begin{array}{l}\text { The US and } \\
\text { Germany }\end{array}$ & Qualitative & $\begin{array}{l}\text { Work-family experiences of } \\
\text { female managers }\end{array}$ \\
\hline $\begin{array}{l}\text { Phang and Lee } \\
\text { (2009) }\end{array}$ & J.Employ.Couns. & Korea & Interview study & $\begin{array}{l}\text { Social support to maintain } \\
\text { work-family }\end{array}$ \\
\hline $\begin{array}{l}\text { Pinto and Maia } \\
(2015)\end{array}$ & $\begin{array}{l}\text { Acad.-Rev. } \\
\text { Latinoam. Adm. }\end{array}$ & Portugual & $\begin{array}{l}\text { Qualitative- } \\
\text { exploratory study }\end{array}$ & $\begin{array}{l}\text { Work-life demands and } \\
\text { coping mechanisms }\end{array}$ \\
\hline $\begin{array}{l}\text { Poppleton et al. } \\
\text { (2008) }\end{array}$ & $\begin{array}{l}\text { J.Occup.Organ.P } \\
\text { sychol. }\end{array}$ & - & Qualitative & $\begin{array}{l}\text { Positive and negative aspects } \\
\text { of work-family relationships }\end{array}$ \\
\hline $\begin{array}{l}\text { Pratt and Rosa } \\
\text { (2003) }\end{array}$ & Acad. Manage. J. & The US & Qualitative & $\begin{array}{l}\text { Work-family experiences } \\
\text { and commitment of network } \\
\text { marketing organization } \\
\text { employees }\end{array}$ \\
\hline
\end{tabular}




\begin{tabular}{|c|c|c|c|c|}
\hline Author(s) (Year) & $\begin{array}{l}\text { Periodical } \\
\text { Abbrev }\end{array}$ & Country & Research Approach & Focus \\
\hline $\begin{array}{l}\text { Radcliffe and } \\
\text { Cassell (2014) }\end{array}$ & Hum. Relat. & The UK & Qualitative & Work-family solutions \\
\hline $\begin{array}{l}\text { Radcliffe and } \\
\text { Cassell (2015) }\end{array}$ & $\begin{array}{l}\text { J. Occup. Organ. } \\
\text { Psychol. }\end{array}$ & - & $\begin{array}{l}\text { Qualitative- } \\
\text { longitudinal diary } \\
\text { study }\end{array}$ & $\begin{array}{l}\text { Flexible working within } \\
\text { dual-earner couples }\end{array}$ \\
\hline $\begin{array}{l}\text { Rafnsdottiró and } \\
\text { Heijstra (2013) }\end{array}$ & $\begin{array}{l}\text { Gend.Work.Orga } \\
\mathrm{n} .\end{array}$ & Iceland & Qualitative & $\begin{array}{l}\text { Work-family and use of } \\
\text { flexibility }\end{array}$ \\
\hline Ranson (2005) & $\begin{array}{l}\text { Can. Rev. } \\
\text { Sociol. } \\
\text { Anthropol.-Rev. }\end{array}$ & Canada & Qualitative & Motherhood and engineering \\
\hline $\begin{array}{l}\text { Ravenswood and } \\
\text { Markey (2011) }\end{array}$ & J.Ind.Relat. & $\begin{array}{l}\text { New } \\
\text { Zealand }\end{array}$ & Case study approach & $\begin{array}{l}\text { Family-friendly provisions } \\
\text { negotiated by different } \\
\text { unions }\end{array}$ \\
\hline Reeve et al. (2012) & J.Ind.Relat. & Australia & - & Family-friendly policies \\
\hline Ridge (2007) & J.Soc.Policy & The UK & Qualitative & $\begin{array}{l}\text { Children's accounts of their } \\
\text { lives both before and after } \\
\text { having working mothers }\end{array}$ \\
\hline $\begin{array}{l}\text { Rigby and O'Brien- } \\
\text { Smith (2010) }\end{array}$ & $\begin{array}{l}\text { Work } \\
\text { Employ.Soc. }\end{array}$ & The UK & Qualitative & Union intervention strategies \\
\hline $\begin{array}{l}\text { Root and Wooten } \\
(2008)\end{array}$ & $\begin{array}{l}\text { Hum.Resour.Ma } \\
\text { nage. }\end{array}$ & The US & Ethnographic study & $\begin{array}{l}\text { Work-family experiences of } \\
\text { father shift workers }\end{array}$ \\
\hline $\begin{array}{l}\text { Root and Young } \\
\text { (2011) }\end{array}$ & $\begin{array}{l}\text { Ann. Am. Acad. } \\
\text { Polit. Soc. } \\
\text { Sci.Science }\end{array}$ & The US & Qualitative research & $\begin{array}{l}\text { Work-family balance and } \\
\text { workplace flexibility }\end{array}$ \\
\hline Sav et al. (2014) & Pers. Rev. & Australia & Qualitative & Work-family strategies \\
\hline Sayah (2013) & $\begin{array}{l}\text { New } \\
\text { Technol.Work } \\
\text { Employ. }\end{array}$ & Germany & Qualitative & $\begin{array}{l}\text { ICT as work-family } \\
\text { solutions }\end{array}$ \\
\hline Schilling (2015) & $\begin{array}{l}\text { Gend. Work. } \\
\text { Organ. }\end{array}$ & Germany & Qualitative & $\begin{array}{l}\text { Intersection of age, } \\
\text { qualification, and work-life } \\
\text { trajectories }\end{array}$ \\
\hline $\begin{array}{l}\text { Secret and } \\
\text { Swanberg (2008) }\end{array}$ & $\begin{array}{l}\text { Public Personnel } \\
\text { Manage. }\end{array}$ & - & Case study & $\begin{array}{l}\text { Work-family issues of } \\
\text { municipal employees }\end{array}$ \\
\hline $\begin{array}{l}\text { Singley and Hynes } \\
(2005)\end{array}$ & Gend. Soc. & The US & Qualitative & $\begin{array}{l}\text { Work-family policies in the } \\
\text { decisions dual-earner } \\
\text { married couples }\end{array}$ \\
\hline Skinner et al. (2014) & $\begin{array}{l}\text { Asia Pac. J. } \\
\text { Hum. Resour. }\end{array}$ & Australia & Qualitative & $\begin{array}{l}\text { Work-family across the life } \\
\text { course }\end{array}$ \\
\hline Skinner et al. (2011) & $\begin{array}{l}\text { Asia Pac. J. } \\
\text { Hum. Resour. }\end{array}$ & Australia & $\begin{array}{l}\text { Qualitative } \\
\text { description }\end{array}$ & $\begin{array}{l}\text { Work-family experiences of } \\
\text { nurses and work-family } \\
\text { policies and practices of } \\
\text { improve the WFI }\end{array}$ \\
\hline Solomon (2011) & Soc. Sci. J. & The US & Qualitative & $\begin{array}{l}\text { Untenured male and female } \\
\text { assistant professors' work- } \\
\text { family }\end{array}$ \\
\hline $\begin{array}{l}\text { Stalp and Conti } \\
\text { (2011) }\end{array}$ & $\begin{array}{l}\text { Gend.Work.Orga } \\
\text { n. }\end{array}$ & The US & Interview study & $\begin{array}{l}\text { Work-family experiences of } \\
\text { quilters }\end{array}$ \\
\hline $\begin{array}{l}\text { Stanko and } \\
\text { Beckman (2015) }\end{array}$ & Acad. Manage. J. & The US & Interview study & $\begin{array}{l}\text { Impact of organizational } \\
\text { controls on work and non- } \\
\text { work interactions }\end{array}$ \\
\hline Sturges (2012) & Hum. Relat. & The UK & Qualitative & $\begin{array}{l}\text { The WFI among young } \\
\text { professionals }\end{array}$ \\
\hline $\begin{array}{l}\text { Suess and Sayah } \\
\text { (2013) }\end{array}$ & Eur. Manag. J. & Germany & Qualitative & $\begin{array}{l}\text { Work-family and contract } \\
\text { working }\end{array}$ \\
\hline Thinnam (2011) & $\begin{array}{l}\text { Hum.Resour.Dev } \\
\text {.Q. }\end{array}$ & Thailand & $\begin{array}{l}\text { Phenomenological } \\
\text { research }\end{array}$ & $\begin{array}{l}\text { Work-family experiences of } \\
\text { Thai working mothers }\end{array}$ \\
\hline $\begin{array}{l}\text { Tracy and Rivera } \\
(2010)\end{array}$ & $\begin{array}{l}\text { Manage.Commu } \\
\text { n.Q. }\end{array}$ & The US & Interview study & Work-family and gender \\
\hline
\end{tabular}




\begin{tabular}{|c|c|c|c|c|}
\hline Author(s) (Year) & $\begin{array}{l}\text { Periodical } \\
\text { Abbrev }\end{array}$ & Country & Research Approach & Focus \\
\hline Trefalt (2013) & Acad. Manage. J. & The US & Qualitative study & Boundary work process \\
\hline $\begin{array}{l}\text { Tsaur and Lin } \\
\text { (2014) }\end{array}$ & $\begin{array}{l}\text { Tourism } \\
\text { Manage. }\end{array}$ & Taiwan & Qualitative approach & $\begin{array}{l}\text { Work-family experiences of } \\
\text { tour leaders }\end{array}$ \\
\hline $\begin{array}{l}\text { Turbine and Riach } \\
\text { (2012) }\end{array}$ & $\begin{array}{l}\text { Gend.Work.Orga } \\
\mathrm{n} .\end{array}$ & Russia & Ethnography & Women work-family choices \\
\hline $\begin{array}{l}\text { Turner and } \\
\text { Norwood (2013) }\end{array}$ & Hum. Relat. & The US & $\begin{array}{l}\text { Phenomenology } \\
\text { (Hermeneutic } \\
\text { perspective) }\end{array}$ & $\begin{array}{l}\text { Organizational breastfeeding } \\
\text { support }\end{array}$ \\
\hline Uttal (1996) & Gend. Soc. & The US & Qualitative & Motherhood and childcare \\
\hline $\begin{array}{l}\text { Vazquez-Carrasco } \\
\text { et al. (2012) }\end{array}$ & Qual. Quant. & Spain & Qualitative & Women in management \\
\hline $\begin{array}{l}\text { von Borell de } \\
\text { Araujo et al. (2015) }\end{array}$ & $\begin{array}{l}\text { J. Manage. } \\
\text { Psychol. }\end{array}$ & Brazil & Qualitative & $\begin{array}{l}\text { Individual-level strategies } \\
\text { for balancing work and } \\
\text { home demands }\end{array}$ \\
\hline Watts (2009) & $\begin{array}{l}\text { Gend.Work.Orga } \\
\mathrm{n} .\end{array}$ & The UK & Qualitative & $\begin{array}{l}\text { Work-family among women } \\
\text { civil engineers }\end{array}$ \\
\hline $\begin{array}{l}\text { Weigt and Solomon } \\
(2008)\end{array}$ & $\begin{array}{l}\text { Gend.Work.Orga } \\
\text { n. }\end{array}$ & The US & Qualitative & $\begin{array}{l}\text { Work-family strategies of } \\
\text { low wage service workers } \\
\text { and assistant professors }\end{array}$ \\
\hline Weststar (2012) & $\begin{array}{l}\text { Relat.Ind.- } \\
\text { Ind.Relat. }\end{array}$ & Canada & Case study & $\begin{array}{l}\text { Parental leave arrangements } \\
\text { among faculty }\end{array}$ \\
\hline Wetlesen (2013) & $\begin{array}{l}\text { Gend.Work.Orga } \\
\mathrm{n} \text {. }\end{array}$ & Norway & Interview study & $\begin{array}{l}\text { Childhood memories about } \\
\text { care arrangements, relations } \\
\text { to parents and parental } \\
\text { gender roles }\end{array}$ \\
\hline Wharton (1994) & Gend. Soc. & - & Interview study & $\begin{array}{l}\text { Flexible Scheduling and } \\
\text { work-family }\end{array}$ \\
\hline Wiersma (1994) & Hum.Relat. & The US & Qualitative & $\begin{array}{l}\text { Work-family strategies of } \\
\text { dual career couples }\end{array}$ \\
\hline Windebank (2001) & $\begin{array}{l}\text { Work } \\
\text { Employ.Soc. }\end{array}$ & $\begin{array}{l}\text { France and } \\
\text { the UK }\end{array}$ & $\begin{array}{l}\text { Case study (cross- } \\
\text { national comparative } \\
\text { study) }\end{array}$ & Work-family policy \\
\hline
\end{tabular}

